Landslides (2021) 18:303-319 DOI 10.1007/s10346-020-01482-8

Received: 30 January 2020

Accepted: 6 July 2020

Published online: 26July 2020

(c) The Author(s) 2020

\section{Settimio Ferlisi - Antonio Marchese - Dario Peduto \\ Quantitative analysis of the risk to road networks exposed to slow-moving landslides: a case study in the Campania region (southern Italy)}

Abstract This paper shows the results of a study aimed at quantitatively estimating - in terms of direct (repair) costs, at large scale (1:5000) - the slow-moving landslide risk to a road network assumed as undamaged as well as the consequences to the same network in damaged conditions. The newly conceived methodological approaches address some challenging tasks concerning (i) the hazard analysis, which is expressed in terms of probability of occurrence of slow-moving landslides with a given intensity level that, in turn, is established based on empirical fragility curves, and (ii) the consequence analysis, which brings to the generation of time-dependent vulnerability curves. Their applicability is successfully tested in a case study in the Campania region (southern Italy) for which both very high-resolution DInSAR data and information gathered from in situ surveys on the severity of damage sustained by the selected road sections are available. Benefits associated with the use of the obtained results in informed decision-making processes are finally discussed.

Keywords Slow-moving

landslides $\cdot$ Roads $\cdot$ DInSAR $\cdot$ Damage $\cdot$ Vulnerability

curves $\cdot$ QRA

\section{Introduction}

Road infrastructure plays a key role in the economic development of a society. For this reason, ensuring its functionality and safety conditions over time is one of the most important and, at the same time, demanding tasks that central and local authorities are asked to undertake. Indeed, owing to their typical linear extent, roads often develop within different geological contexts, each of them prone to given landslide types that originate risks to traveling persons and to roads themselves, the latter being associated with socio-economic impacts (including indirect costs) such as prolongation of travel time and missed trips (Argyroudis et al. 2019; Hackl et al. 2018). Addressing this issue involves carrying out activities aimed at predicting and (eventually) preventing the above risks, taking into account operational and economic constraints (Fell et al. 2005; Winter 2019). As far as the forecasting activities are concerned, they may consist of qualitative or quantitative risk analyses.

The qualitative risk analysis "uses word form, descriptive, or numeric rating scales to describe the magnitude of potential consequences and the likelihood that those consequences will occur" (Fell et al. 2008). Implemented methods make use of scoring systems and ranking matrices to be applied to a large number of slopes. The obtained outcomes (i) facilitate decision-makers to compare (i.e., evaluate and rank) the estimated "relative" risks and (ii) foster the prioritization of slopes requiring follow-up actions (i.e., study, repair, or maintenance), the cost of the latter being preliminarily assessed (Fell et al. 2005; Pantelidis 2011; Wong
2005). Applications of scoring systems tailored for roads mainly deal with cut slopes prone to first-time landslides, such as rock falls (Budetta 2004; Budetta and Nappi 2013; Bunce et al. 1997; Ferlisi et al. 2012; Li et al. 2009; Vishal et al. 2017); anyway, scoring systems are also conceived and applied to roads threatened by soil cuttings/embankments (Liang et al. 2006; Lowell and Morin 2000; ODOT 2001; Wong 1998) and natural slopes (Escario et al. 1997). Recently, Pellicani et al. (2017) tested the applicability of ranking matrices to the main road network of a large area of southern Italy affected by different landslide types, including existing ones (e.g., active landslides slowly moving on buried sliding surfaces).

The quantitative risk analysis (QRA) is "based on numerical values of the probability, vulnerability, and consequences, and resulting in a numerical value of the risk" (Fell et al. 2008); accordingly, QRA allows one to estimate "absolute" risks in terms of probability of a given level of loss, accounting for the uncertainties associated with input parameters (Fell et al. 2005; Ho 2004; Macciotta et al. 2016). Formal methods aimed at analyzing the factors (hazard and consequences) concurring to the risk definition are well-described in the scientific literature (Corominas et al. 2014; Fell et al. 2005; Ho et al. 2000; Wong 2005; Wong et al. 1997; among others); on the other hand, QRA requires input data more accurate (both in quality and quantity) than those adopted in qualitative risk analyses, along with high-resolution digital elevation/terrain models and detailed information on exposed elements (van Westen et al. 2008). The QRA outcomes can be presented in terms of annual risk, e.g., the probability that a particular person-for instance, the most exposed one-may lose his/her life or the expected repair (direct) costs (e.g., €/annum). The scientific literature provides several examples referring to first-time landslide (i.e., rock fall or debris flow) risk to people on moving/stopped vehicles along roads (Budetta 2002; Budetta et al. 2016; Bunce et al. 1997; Hungr et al. 1999; Ferlisi et al. 2012; Lentini et al. 2019; Mavrouli et al. 2019; Roberds 2005; Unterrader et al. 2018; Winter 2018; Winter and Wong 2020; Wong and Winter 2018) whereas very limited in number are the contributions specifically oriented to the quantitative estimation of the risk to roads affected by existing landslides.

For a study area in Belgium and based on focus and semistructured interviews with involved stakeholders, Vranken et al. (2013) quantitatively estimated the costs of measures (in $€ /$ annum) to repair or prevent the landslide-induced damage. Lu et al. (2014), updating the work of Catani et al. (2005), presented a GIS-based landslide risk zoning map that makes use of remote sensing data to provide-on a pixel basis-the expected losses (in $€$ ) to the built environment (including roads) in slowmoving landslide-affected areas of the Arno river Basin (Italy) considering five temporal predictions $(2,5,10,20$, and 30 years). Peng et al. (2015) performed a risk analysis in the Three Gorges 
area (China) taking into account the repair costs for roads; the results are expressed in $10^{3} ¥$ per map cell over a period of 10 years. Mavrouli et al. (2019) presented a procedure aimed at quantitatively estimating (as multiples of a unit cost equalling $€$ 1000) the annual risk to given stretches of a road network in Spain exposed to different dangers, including slow-moving landslides with permanent or episodic activity.

In all encountered cases, the expected losses to or repair costs of exposed roads are computed (i) implicitly assuming that roads themselves are undamaged (as initial condition) and (ii) considering a priori established time intervals. In reality, roads exposed to slow-moving landslides are often already damaged before carrying out the risk analysis; furthermore, the road damage severity (and vulnerability itself) is time-dependent since it may increase as cumulative displacements of interacting slow-moving landslide bodies progressively increase.

These issues are addressed in this paper whose main novelty relies on the joint use of remote sensing and road damage data for the quantitative estimation —at large scale (1:500o)—of slow-moving landslide hazard and related consequences (vulnerability $\times$ reconstruction cost) to either an undamaged or a damaged road network exposed to slow-moving landslides. In this regard, the processing of synthetic aperture radar (SAR) images via differential interferometric algorithms (DInSAR) represents a well-established cost-effective non-invasive technique capable of providing displacement time series of affected areas (Antronico et al. 2013; Bianchini et al. 2012; Cascini et al. 2010;
Colesanti and Wasowski 2006; Crosetto et al. 2018; Herrera et al. 2013; Tofani et al. 2013; Wasowski and Bovenga 2014), in turn useful to characterize the monitored slow-moving landslides from both geometric and kinematic points of view (Bianchini et al. 2013; Calvello et al. 2017; Cascini et al. 2013; Castaldo et al. 2015; Cigna et al. 2013; Di Maio et al. 2018; Frattini et al. 2018; Gullà et al. 2017; Journault et al. 2018; Raspini et al. 2013, 2017; Rosi et al. 2018). More recently, thanks to the increased availability of very high-resolution sensor datasets (i.e., COSMO-SkyMed and TerraSAR-X), the DInSAR data started to be used within procedures aimed at analyzing the consequences induced by slow-moving landslides on both buildings (Bianchini et al. 2015; Ferlisi et al. 2015, 2019a; Lu et al. 2014; Nicodemo et al. 2017, 2020; Peduto et al. 2016, 2017, 2018, 2019) and road networks (Infante et al. 2018, 2019; Nappo et al. 2019; North et al. 2017; Wasowski and Bovenga 2014, 2015). In the latter case, road damage data can be profitably collected by filling ad hoc predisposed fact-sheets during field surveys, provided that a system for classifying the damage severity has been established, as operated in the present work for a road network in the Campania region (southern Italy).

\section{The proposed methodologies}

\section{Quantitative risk analysis}

The proposed methodology for the quantitative analysis of the slow-moving landslide risk to an undamaged road network (Fig. 1) involves carrying out sequential activities according to

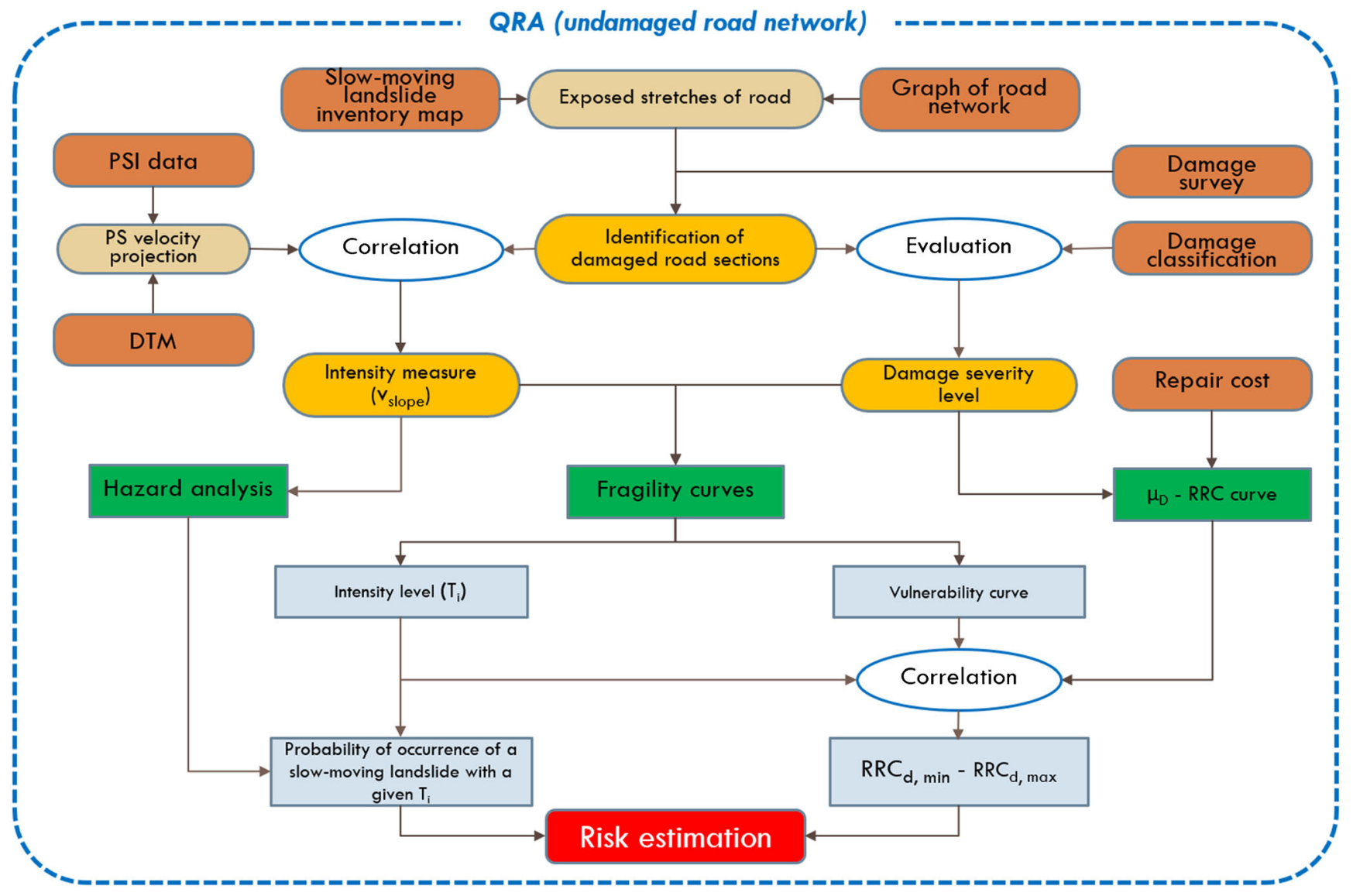

Fig. 1 Flowchart of the proposed methodology for QRA 
the general framework provided by Fell et al. (2005). In particular, these activities are essentially aimed at (i) characterizing the slow-moving landslides affecting the study area, (ii) analyzing their probability of occurrence, (iii) predicting the consequences to the exposed road network, and (iv) quantitatively estimating the risk (in terms of repair costs to be expected over a given period of time). To these aims, spatial data have to be managed in a geographic information system (GIS) environment (Corominas et al. 2014).

As shown in Fig. 1, the slow-moving landslides inventoried in an official map are first selected and categorized according to their type and state of activity (Cruden and Varnes 1996); the extent of affected areas is also retrieved. Exposed (or at risk) stretches of road are then identified by overlaying the landslide inventory map with the graph of road network and each of them is later surveyed in order to detect the severity level of visual damage (if any) to be assigned to road sections (within stretches). The latter are linear elements, traced orthogonally to the road centerline at 1:5000 scale, which indicate where the landslide-induced damage-on average-concentrates. Indeed, a given exposed stretch may have more than one section exhibiting either the same or different damage severity levels.

The damage severity is classified based on a system, adapted from the one first proposed by Mansour et al. (2011) and later updated by Mavrouli et al. (2019), including four levels:

- $\mathrm{D}_{\mathrm{o}}$ (negligible): road pavement deformation and cracks are absent or rarely visible (Fig. 2a);

- $\mathrm{D}_{1}$ (from very low to low): deformation and cracks locally affect the pavement of road without effects on its functionality (Fig. 2b);
- $\mathrm{D}_{2}$ (from moderate to severe): deformation and cracks substantially affect the road pavement, partly or entirely involving the traffic lanes and/or the roadside, so that the reduction of speed limits is required (Fig. 2c);

- $\mathrm{D}_{3}$ (very severe): deformation and cracks definitively compromise the road pavement continuity, partly or entirely involving the traffic lanes and/or the roadside, so that traffic restrictions are required (e.g., yield on the oncoming traffic) (Fig. 2d).

Given a road section, a buffer symmetrically disposed with respect to the road centerline is introduced in order to associate a recorded damage severity level with a certain value of a representative landslide intensity measure (IM). The buffer width is $40 \mathrm{~m}$ in the direction orthogonal to the road centerline, according to the ground resolution of radar sensors and with the general intent to collect as much DInSAR data as possible, whereas the buffer length (along the road centerline) is variable according to the number of damaged road sections and their relative position. In this regard, some indicative examples are shown in Fig. 3.

As far as the IM is concerned, examples in literature dealing with slow-moving landslides analyzed at large scale suggest using a representative velocity along the steepest slope direction ( $\left.\mathrm{v}_{\text {slope }}\right)$. In particular, this suggestion is quite in agreement with Mansour et al. (2011) who propose adopting a generic annual displacement rate of the landslide body, without specifying the main direction of movement; on the other hand, Picarelli (2011) emphasizes the role of cumulative displacement (over a given period of time) in the onset and development of damage to exposed facilities. Mavrouli et al. (2019) basically adhere to both proposals assuming as IM a
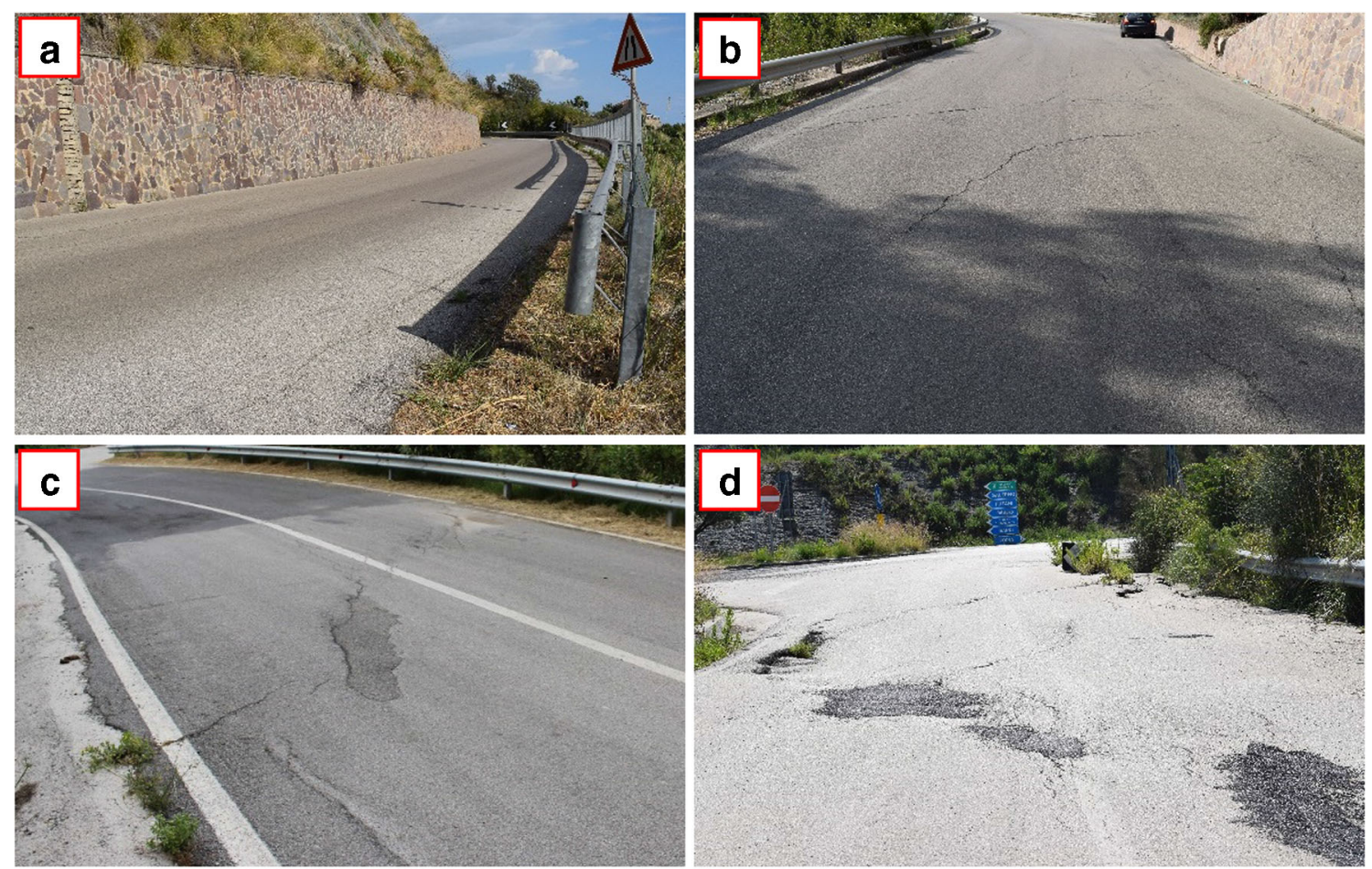

Fig. 2 Road damage severity levels classified as a $D_{0}$ (negligible), $\mathbf{b} D_{1}$ (from very low to low), $\mathbf{c} D_{2}$ (from moderate to severe), and $\mathbf{d} D_{3}$ (very severe) 


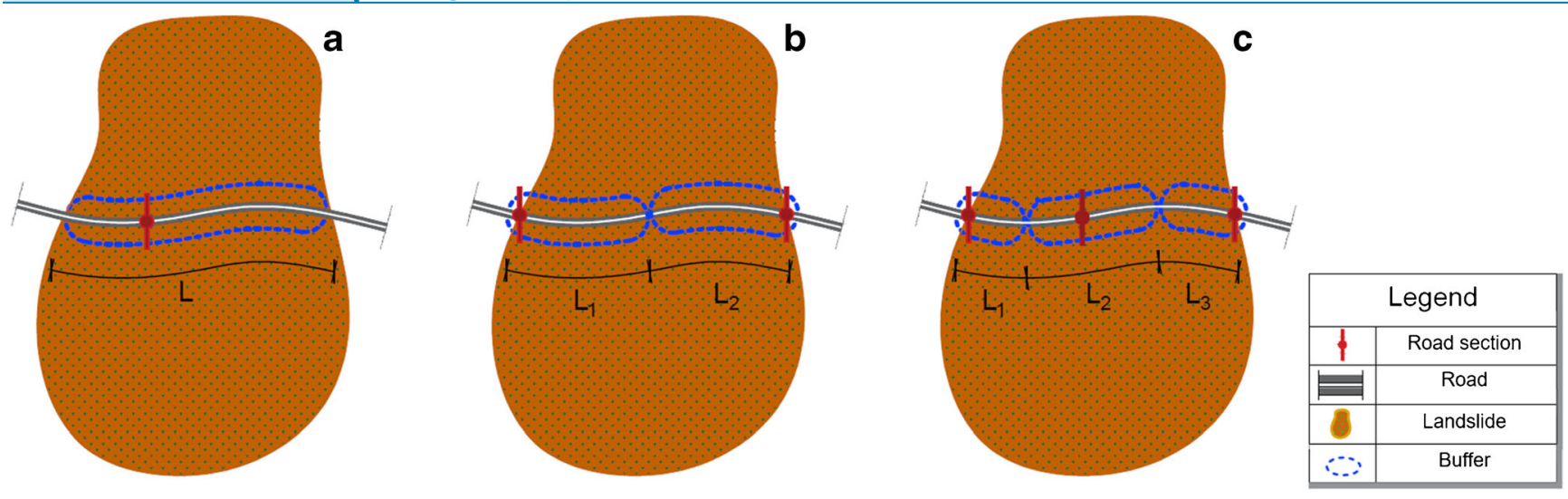

Fig. 3 Examples showing the criteria adopted to define the length of buffer/s in the case of a one road section (the buffer length $L$ coincides with the stretch length); $\mathbf{b}$ two road sections located on the boundary of the slow-moving landslide-affected area (the buffer lengths are equal in value, i.e., $L_{1}=L_{2}$ ); and $c$ three road sections, two located on the boundary and one within the slow-moving landslide-affected area $\left(\mathrm{L}_{1} \neq \mathrm{L}_{3} ; \mathrm{L}_{2}=\mathrm{L}_{1}+\mathrm{L}_{3}\right)$

combination of the maximum monthly horizontal displacement rate and the annual cumulative horizontal displacement.

A generic IM value can be retrieved on the basis of DInSAR data, such as those obtained by way of the persistent scatterer interferometry (PSI). The latter is a technique that involves carrying out a multi-interferogram analysis of multi-temporal SAR images in order to extract long-term high phase stability benchmarks of coherent PSI point targets called persistent scatterers (PS) (Costantini et al. 2008; Ferretti et al. 2001). Accordingly, a $\mathrm{v}_{\text {slope_k }}$ vector (and related modulus) derives from projecting the velocity vector pertaining to the $k$-th PS within a reference area (e.g., a landslide-affected area on the whole or a part of it, such as the buffer considered in this work) from the sensor line of sight $\left(v_{\text {LOS_k }}\right)$ to the steepest slope direction; this implies assuming for each PS a prevalent translational movement (Cascini et al. 2010, 2013; Cigna et al. 2013; Vecchiotti et al. 2017).

Considering that the LOS projection along the steepest slope direction can be biased by errors (Cascini et al. 2010; Colesanti and Wasowski 2006), each PS must be distinguished according to the own scaling factor, namely the constant value by which the modulus of $\mathrm{v}_{\mathrm{LOS} \mathrm{k}}$ must be multiplied in order to obtain the modulus of $\mathrm{v}_{\text {slope_k }}$. This issue was addressed by Cascini et al. (2013) who observed that, for data acquired on single satellite orbits (either ascending or descending), a scaling factor equalling 3.3 represents an acceptable (upper) threshold to select the most reliable projected PS velocity values. In other words, only those PS whose scaling factor is less than 3.3 are "projectable" and, then, can be used for the following quantitative analyses; the remaining PS have to be discarded and appointed as "not projectable" (see also Plank et al. 2012 and Herrera et al. 2013).

In this work, for those buffers covered by at least one projectable PS in either ascending or descending orbit, the $\mathrm{v}_{\text {slope }}$ modulus to be associated with a given buffer is computed as the root mean square PS velocity along the steepest slope direction according to the equations (Cascini et al. 2013):

$\mathbf{v}_{\text {slope }}=\left(\frac{\sum_{\mathrm{k}=1}^{\mathrm{N}} \mathbf{w}_{\mathrm{ck}} \mathbf{v}_{\text {slope } \_\mathrm{k}}^{2}}{\sum_{\mathrm{k}=1}^{\mathrm{N}} \mathbf{w}_{\mathrm{ck}}}\right)^{1 / 2}=\left(\sum_{\mathrm{k}=1}^{\mathrm{N}} \frac{\mathbf{w}_{\mathrm{ck}}}{\mathbf{w}_{\mathrm{cN}}} \mathbf{v}_{\text {slope } \_\mathrm{k}}^{2}\right)^{1 / 2}$ $w_{c k}=\frac{\left(1-\varepsilon_{\min }\right)}{\left(C_{\max }-C_{\min }\right)}\left(C_{k}-C_{\min }\right)+\varepsilon_{\min }$

in which the weight values are established based on the PS coherence (i.e., the higher the PS coherence, the higher the weight value).

In the Eqs. (1a) and (1b), k refers again to the $k$-th PS within the buffer; $\mathrm{N}$ is the total number of PS within the buffer; $\mathrm{w}_{\mathrm{ck}}$ is the weight computed on coherence of the velocity of the $k$-th PS within the buffer; $\mathrm{w}_{\mathrm{cN}}$ is the sum of $\mathrm{w}_{\mathrm{ck}} ; \mathrm{C}_{\max }$ and $\mathrm{C}_{\min }$ are the maximum and the minimum coherence values of the used dataset, respectively; $\mathrm{C}_{\mathrm{k}}$ is the coherence value of the $k$-th PS within the buffer; $\varepsilon_{\text {min }}$ is a given small number used in order to not discard the $k$-th PS with $\mathrm{C}_{\mathrm{k}}=\mathrm{C}_{\mathrm{min}}$. In the analyses, $\varepsilon_{\min }$ value was fixed equal to 0.2 thus assigning a weight of $20 \%$ to the smallest coherence value.

The availability of both IM values and (related) road damage data allows for the generation of empirical fragility curves. To this aim, the frequency of occurrence of each level of damage severity is first calculated for different classes of IM values. Then, using methods commonly adopted in different engineering fields (Ferlisi et al. 2019b; Fotopoulou and Pitilakis 2013; Mavrouli et al. 2014; Negulescu and Foerster 2010; Negulescu et al. 2014; Peduto et al. 2017, 2018, 2019; Pitilakis and Fotopoulou 2015; Saeidi et al. 2009, 2012; Shinozuka et al. 2000; Zhang and Ng 2005), the probability $\mathrm{P}($ ) for a road section (randomly selected from a homogenous sample of road sections) to reach or exceed a certain damage severity level $\left(D_{i}\right)$ for a given value of the selected IM parameter is calculated using a cumulative log-normal distribution function:

$$
P\left(\text { Damage } \geq D_{i} \mid I M\right)=\Phi\left[\frac{1}{\beta_{i}} \ln \left(\frac{I M}{\overline{I M}_{i}}\right)\right] \quad(i=1,2,3)
$$

The fragility parameters (median $\overline{I M}_{i}$ and dispersion $\beta_{\mathrm{i}}$ ) of the standard normal cumulative distribution function $\Phi\left[\_\right]$are computed using the maximum likelihood estimation method (Shinozuka et al. 2003). This method is based on a statistical approach and requires only binary information (damage or no 
damage). In particular, the likelihood function (L) can be expressed as (Shinozuka et al. 2000):

$$
\begin{aligned}
L= & \prod_{j=1}^{Y} P\left(\text { Damage } \geq D_{i} \mid I M_{j}\right)^{x_{j}} \\
& \times\left[1-P\left(\text { Damage } \geq D_{i} \mid I M_{j}\right)\right]^{1-x_{j}}
\end{aligned}
$$

In Eq. (3), $\mathrm{P}\left(\right.$ Damage $\left.\geq D_{i} \mid I M_{j}\right)$ represents the probability of reaching or exceeding a certain $D_{i}$ for a given value of $\operatorname{IM}_{j}(j=1$, $\ldots, \mathrm{Y}$, being $\mathrm{Y}$ the total number of $\mathrm{IM}_{\mathrm{j}}$ values), whereas $\mathrm{x}_{\mathrm{j}}$ is the realization of the Bernoulli random variable $\mathrm{X}_{\mathfrak{j}}$, whose value equals 1 or o depending on whether or not the road section sustains the considered damage severity level under the IM value equal to $\mathrm{IM}_{\mathrm{j}}$. The two parameters $\overline{I M}_{i}$ and $\beta_{i}$ can be computed by solving the following equations to maximize $\ln (\mathrm{L})$ and hence $\mathrm{L}$ :

$\frac{d \ln (L)}{d \bar{M}_{i}}=\frac{d \ln (L)}{d \beta_{i}}=0$

Once the fragility curves are generated, vulnerability curves-relating the selected IM parameter with the average damage $\left(\mu_{D}\right)$ expected to the road sections - can be derived by fitting the $\mu_{D}\left(I_{j}\right)$ data obtained as (adapted from Pitilakis and Fotopoulou 2015):

$\mu_{D}\left(I M_{j}\right)=\sum_{i=1}^{3} P_{i}\left(I M_{j}\right) \times d_{i} \quad(j=1, \ldots, Y)$

where $P_{i}\left(I M_{j}\right)$ is the discrete probability (to be retrieved on the basis of the fragility curves for a given value of $\mathrm{IM}_{\mathrm{j}}$ ) associated with a damage severity level $\left(D_{i}\right)$ whose numerical index equals $d_{i}$ (taken for this application as 1,2 , and 3 for $D_{1}, D_{2}$, and $D_{3}$, respectively). According to Lagomarsino and Giovinazzi (2006) the tangent hyperbolic function can be used as regression model, so that:

$\mu_{D}=C_{1}\left[C_{2}+\tanh \left(C_{3} \times I M+C_{4}\right)\right]$.

In Eq. (6), $c_{1}, c_{2}, c_{3}$, and $c_{4}$ are four coefficients that must be determined for the considered sample of road sections.

The fragility curves also allow one to retrieve the intensity thresholds $\left(T_{i}, i=1,2,3\right)$ which represent values of IM in correspondence of a probability of reaching or exceeding a given damage severity level equalling the $5 \%$ (Zhang and $\mathrm{Ng}$ 2005). This choice can be motivated by the need to limit IM to values compatible with the effectiveness of risk mitigation measures designed according to a performance-based approach that involves reducing the evolution of slope displacements within an estimated time interval, by limiting their magnitude to a target value (Galli and di Prisco 2013). Based on these thresholds, four different ranges of the IM or intensity levels-associated with a nominal scale-are established (Table 1). Then, by carrying out the probabilistic analysis of the IM values used for the generation of fragility curves, the probability of occurrence of slow-moving landslides with a given intensity level $\left(\mathrm{P}_{(\mathrm{SML}), \mathrm{d}}\right.$, with $\left.\mathrm{d}=0, \ldots, 3\right)$ is retrieved.

The next step involves generating the $\mu_{D}$-RRC curve based on an official price list coeval to the year for which the most recent road damage data are available. The RRC, representing the relative repair cost (ranging from o to 1), is given by the ratio between the repair cost and the reconstruction cost (per unit road length, e.g., $1 \mathrm{~m}$ ).

Finally, the slow-moving landslide risk to the road network $\left(\mathrm{R}_{(\mathrm{RN})}\right)$ is estimated on a quantitative basis. This risk corresponds to the repair costs [in $€$ ] of a road network identical to the one under study from a starting time $t_{\mathrm{o}}$ (in which the road network is assumed as undamaged) to a reference time $t^{\star}$ (equalling the average time required for the full development of damage-i.e., from $\mathrm{D}_{\mathrm{o}}$ to $\mathrm{D}_{3}$-in at least one road section within the observation period). It ranges between a minimum $\left(\mathrm{R}_{(\mathrm{RN}) \text {,min }}\right)$ and a maximum $\left(\mathrm{R}_{(\mathrm{RN}) \text { max }}\right)$ value according to the following equations:

$R_{(R N), \min }=\left[P_{(S M L), 0} \frac{\sum_{b=1}^{A} L_{b}}{L_{D I n S A R}} R R C_{0, \min }+P_{(S M L), 1} \frac{\sum_{b=1}^{B} L_{b}}{L_{D I n S A R}} R R C_{1, \min }+P_{(S M L), 2} \frac{\sum_{b=1}^{C} L_{b}}{L_{D I n S A R}} R R C_{2, \min }+P_{(S M L), 3} \frac{\sum_{b=1}^{D} L_{b}}{L_{D I n S A R}} R R C_{3, \min }\right] \cdot\left(\frac{L_{r s}}{L_{r n}}\right) \cdot L_{r n} \cdot U C^{*}$

$R_{(R N), \max }=\left[P_{(S M L), 0} \frac{\sum_{b=1}^{A} L_{b}}{L_{D I n S A R}} R R C_{0, \max }+P_{(S M L), 1} \frac{\sum_{b=1}^{B} L_{b}}{L_{D I n S A R}} R R C_{1, \max }+P_{(S M L), 2} \frac{\sum_{i=1}^{C} L_{b}}{L_{D I n S A R}} R R C_{2, \max }+P_{(S M L), 3} \frac{\sum_{b=1}^{D} L_{b}}{L_{D I n S A R}} R R C_{3, \max }\right] \cdot\left(\frac{L_{r s}}{L_{r n}}\right) \cdot L_{r n} \cdot U C^{*}$

where $\mathrm{L}_{\mathrm{b}}$ is the length (in meters) of the $b$-th buffer covered by PSI data (being A, B, C, D the total number of buffers associated with landslides of either negligible, or low, or moderate, or high intensity level), $\mathrm{L}_{\mathrm{DInSAR}}$ is the overall length (in meters) of the buffers covered by PSI data, $\mathrm{L}_{\mathrm{rs}}$ is the overall length (in meters) of the entire sample of exposed road stretches, $\mathrm{L}_{\mathrm{rn}}$ is the overall length (in meters) of the entire road network. Based on the $\mu_{D}$-RRC curve, the values of $\mathrm{RRC}_{\mathrm{d} \text {,min }}$ and $\mathrm{RRC}_{\mathrm{d} \text {,max }}$ are associated with the minimum
$\left(\mu_{D_{-} d \text {,min }}\right)$ and the maximum $\left(\mu_{D_{-} \mathrm{d} \text {,max }}\right)$ values of $\mu_{\mathrm{D}}$ for a given intensity level, respectively $(\mathrm{d}=0, \ldots, 3)$. For instance, referring to the intensity level "moderate" and making use of the vulnerability curve, the value of $\mu_{\mathrm{D}_{-} 2 \text {,min }}$ relates to the intensity threshold $\mathrm{T}_{2}$ whereas the value of $\mu_{\mathrm{D}_{2} \text {, max }}$ to $\mathrm{T}_{3}$. Furthermore, it must be noticed that $\mathrm{RRC}_{\mathrm{o} \text {,min }}$ has to be associated with the costs to be incurred in order to guarantee the ordinary maintenance of the road network, whereas $\mathrm{RRC}_{3, \max }$ is equal to 1 . $\mathrm{UC}^{*}$ is the unit cost (UC) of 
Table 1 Intensity levels with the associated nominal scale

Intensity level

Nominal scale

\begin{tabular}{cl}
$0<\mathrm{v}_{\text {slope }} \leq \mathrm{T}_{1}$ & Negligible \\
\hline $\mathrm{T}_{1}<\mathrm{v}_{\text {slope }} \leq \mathrm{T}_{2}$ & Low \\
\hline $\mathrm{T}_{2}<\mathrm{v}_{\text {slope }} \leq \mathrm{T}_{3}$ & Moderate \\
\hline $\mathrm{V}_{\text {slope }}>\mathrm{T}_{3}$ & High \\
\hline
\end{tabular}

reconstruction to be referred to the time $t^{*}$ (in years) by using the compound interest formula:

$\mathrm{UC}^{\star}=\mathrm{UC}_{\mathrm{o}} \times(1+\mathrm{r})^{\mathrm{t}^{*}}$

wherein $\mathrm{UC}_{\mathrm{o}}$ is the $\mathrm{UC}$ at $\mathrm{t}_{\mathrm{o}}$ and $\mathrm{r}$ is the nominal annual interest rate.

\section{Quantitative consequence analysis}

To estimate the repair costs of the road network under consideration (which is already damaged) in a time $t$ greater than $t^{\star}$, one can proceed as shown in Fig. 4.

In particular:

(a) the "actual" relative repair cost $\left(\mathrm{RRC}_{\mathrm{actual}}\right)$ of the road network is first calculated considering the entire sample (X) of road sections with recorded damage by way of the equation:

$$
R R C_{\text {actual }}=\frac{R R C_{0} \sum_{b=1}^{P} L_{b}+R R C_{1} \sum_{b=1}^{Q} L_{b}+R R C_{2} \sum_{b=1}^{R} L_{b}+R R C_{3} \sum_{b=1}^{S} L_{b}}{\sum_{b=1}^{P+Q+S} L_{b}}
$$

wherein $R R C_{d}$ is the relative repair cost for $\mu_{D}=d(d=0, \ldots$, 3) and $P, Q, R$, and $S$ are the total number of road sections (each one associated with a buffer having a length $\mathrm{L}_{\mathrm{b}}$ ) whose recorded damage equals $D_{0}, D_{1}, D_{2}$, and $D_{3}$, respectively;

(b) then, by using the $\mu_{D}-R R C$ curve, the value of $\mu_{D}$, actual corresponding to the calculated value of $\mathrm{RRC}_{\mathrm{actual}}$ is estimated;

(c) this datum (i.e., $\mu_{\mathrm{D}}$, actual), in turn, allows one to retrieve-based on the vulnerability curve-the value of IM that, on average, is representative of the road sections interacting with slow-moving landslides ( $\left.\mathrm{v}_{\text {slope, actual }}\right)$;

(d) assuming that the landslide bodies are moving according to a $\mathrm{v}_{\text {slope }}$ that is keeping constant over time, in a time interval $\Delta \mathrm{t}=\mathrm{t}-\mathrm{t}^{*}$ (wherein $\mathrm{t}>\mathrm{t}^{*}$, having conservatively hypothesized that the damage actually exhibited by the road network developed in $t^{*}$ years) the average cumulative displacement exhibited by the landslide bodies along the steepest slope direction will be equal to $\Delta \mathrm{s}=\mathrm{v}_{\text {slope, actual }} \times \Delta \mathrm{t}$;

(e) since $s=v_{\text {slope, actual }} \times t^{*}$ (where $s$ is the average cumulative displacement exhibited by the landslide bodies in a time $t^{*}$, starting from $t_{0}$ ), in order to have at $t^{\star}$ an average cumulative displacement equalling $s+\Delta s$, the average velocity must be equal to $v_{1}=(s+\Delta s) / t^{*}$;

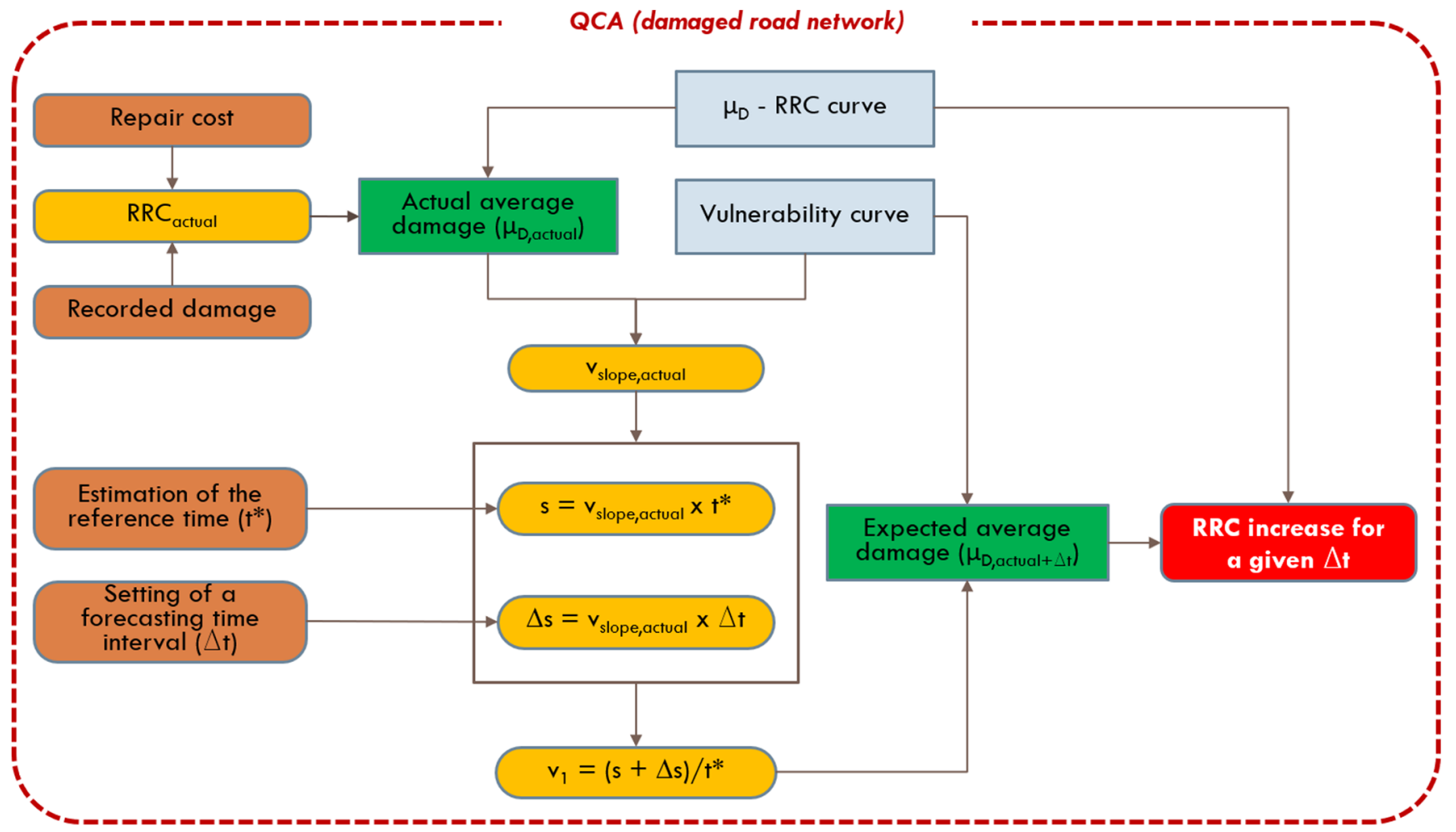

Fig. 4 Flowchart of the proposed methodology for QCA 
(f) based on the vulnerability curve, the knowledge of $v_{1}$ in value allows one to estimate the average damage expected in a time $t\left(\mu_{D}\right.$, actual $\left.+\Delta t\right)$ considering an average velocity equal to $v_{1}$;

(g) finally, the value of $\mu_{D}$, actual $+\Delta t$ can be introduced in the $\mu_{D^{-}}$ $\mathrm{RRC}$ curve to obtain the value of $\mathrm{RRC}_{\mathrm{actual}+\Delta \mathrm{t}}$ from which, by subtracting the value of $\mathrm{RRC}_{\mathrm{actua}}$, the increment in value (from $t^{*}$ to $t$ ) of RRC can be retrieved.

On the other hand, the hypothesis that the landslides are moving with a constant $\mathrm{v}_{\text {slope }}$ allows for the point-by-point generation of a vulnerability curve referring to the time $t$ based on the available one which refers to $t^{*}$. To this aim, it is possible to proceed as described above (sub-points d), (e), and (f)) by arbitrarily choosing different $\mathrm{v}_{\text {slope }}$ values (more values are chosen, more accurate will be the estimate).

Case study: Road network and available dataset

The analyzed road network develops within a territory (Fig. 5) extending for about $1600 \mathrm{~km}^{2}$ and located within the national park of "Cilento, Vallo di Diano, and Alburni" (south-western part of the Campania region, southern Italy).

From a geological point of view (Fig. 5a), owing to the long-time and complex lithogenetic and orogenetic history, several lithostratigraphic units in form of nappes and/or irregular sequences can be distinguished in the territory under consideration. As deeply discussed by Santangelo et al. (2005), such units can be first categorized into internal units (mainly constituted by marly calcarenites, calcilutites, clay, often siliceous, sandy clays, sandstones, and conglomerates) and external units (including carbonate and terrigenous sediments), according to the original position before the tectonic deformation. One of the most widespread group in the study area is represented by the neogenic synorogenic units of the Miocene age (made up of clays, sandstones, and conglomerates with wild-flysch facies) deposited in a basin formed on top of advancing thrusts. Finally, the quaternary postorogenic units include continental and marine sediments whose deposition took place after the final emersion of the area in the Late PlioceneEarly Pleistocene.

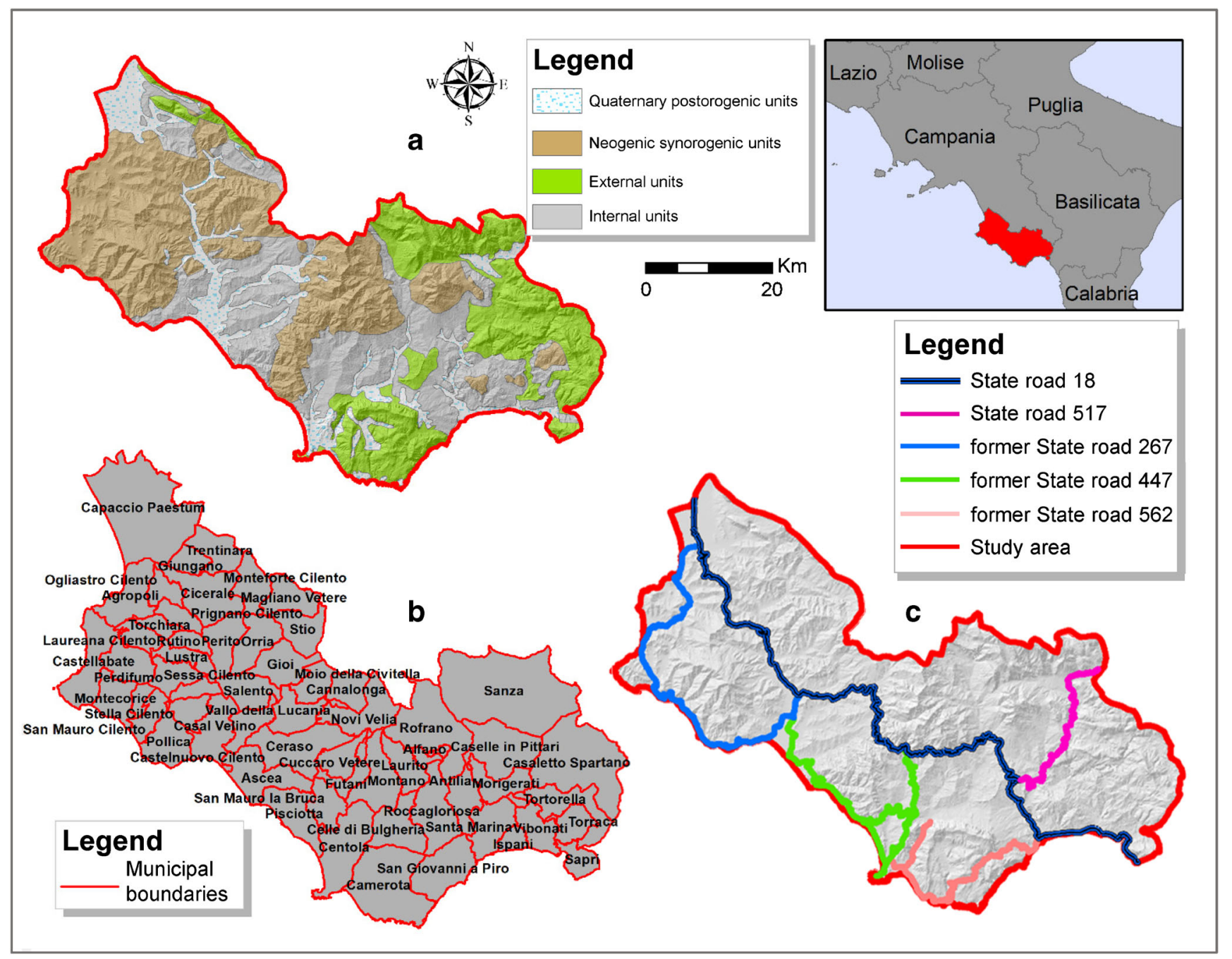

Fig. 5 a Geological map and $\mathbf{b}$ municipalities of the territory where $\mathbf{c}$ the analyzed road network develops 
Table 2 Length of roads in the study area

$$
\text { Road }
$$

$$
\text { State road } 18
$$

State road 517

40

former State road 267

73

former State road 447

former State road 562

The territory is studded with small towns, some of them representing renowned touristic spots especially in the summer season; globally, it counts 59 municipalities (Fig. 5b).

As for the road network, it mainly consists of urban roads and suburban secondary roads composed by single carriageways with two lanes (one per each traveling direction). The graph of the analyzed network is shown in Fig. $5 \mathrm{c}$, whereas the length of the composing (either State or former State) roads are synthesized in Table 2.

For the territory shown in Fig. 5a, a landslide inventory map at 1:5000 scale (Fig. 6a) is available as a result of the activities carried out in $\mathbf{2 0 1 2}$ by the former "Sinistra Sele" River Basin Authority within the Hydrogeological Setting Plan - Landslide Risk excerpt (Italian Law 365/2000). It can be noticed that slow-moving landslides (summing up to 14,843 , representing the $83 \%$ out of the total inventoried slope instabilities) can be distinguished among rotational/translational slides, lateral spreads, (earth) flows, deep-seated gravitational slope deformations (DGSD), and creep phenomena (Cruden and Varnes 1996; Hungr et al. 2014). The extent of affected areas is shown in Fig. 6b, whereas Fig. $6 \mathrm{c}$ shows the number and state of activity of different inventoried slowmoving landslide types.

As for DInSAR data, the available dataset is provided by the Italian "Ministry of the Environment and Protection of the Territory and the Sea." It results from the PSI processing of images acquired by COSMO-SkyMed (very high-resolution) radar sensors on both ascending (42 images from May 2011 to March 2014) and descending (42 images from October 2011 to December 2013) orbits. The spatial distribution over the study area of PS is shown in Fig. $7 \mathrm{a}$ for the ascending orbit and in Fig. $7 \mathrm{~b}$ for the descending orbit, along with the corresponding values of the average annual velocity (in $\mathrm{mm} /$ year) computed along the LOS of the radar sensors.

As for road damage data, they were collected by filling-in ad hoc predisposed fact-sheets during field surveys. These fact-sheets are comprised of different sections that allow gathering information on the location of the exposed road stretch, the geological context, the slow-moving landslide type and its state of activity, the recorded damage (with explanatory photos) and its severity level, the PSI data in terms of displacement time series along the steepest slope direction (Fig. 8).

Further damage data were collected by managing the images available in the Google Street View archive for all the considered road sections (with one image per section at least) dating back to September 2008 (since the damage surveys ended in July 2018, this implies that the observation period spans 9.9 years). An example is shown in Fig. 8 with reference to a road section in the municipal territory of Pollica along the former State road 267 damaged by a rotational slide. In this case, Google Street View provides two images that allow us to detect an increase in the damage severity (from $\mathrm{D}_{1}$ to $\mathrm{D}_{3}$ ) within an 8-year period. The same road section is
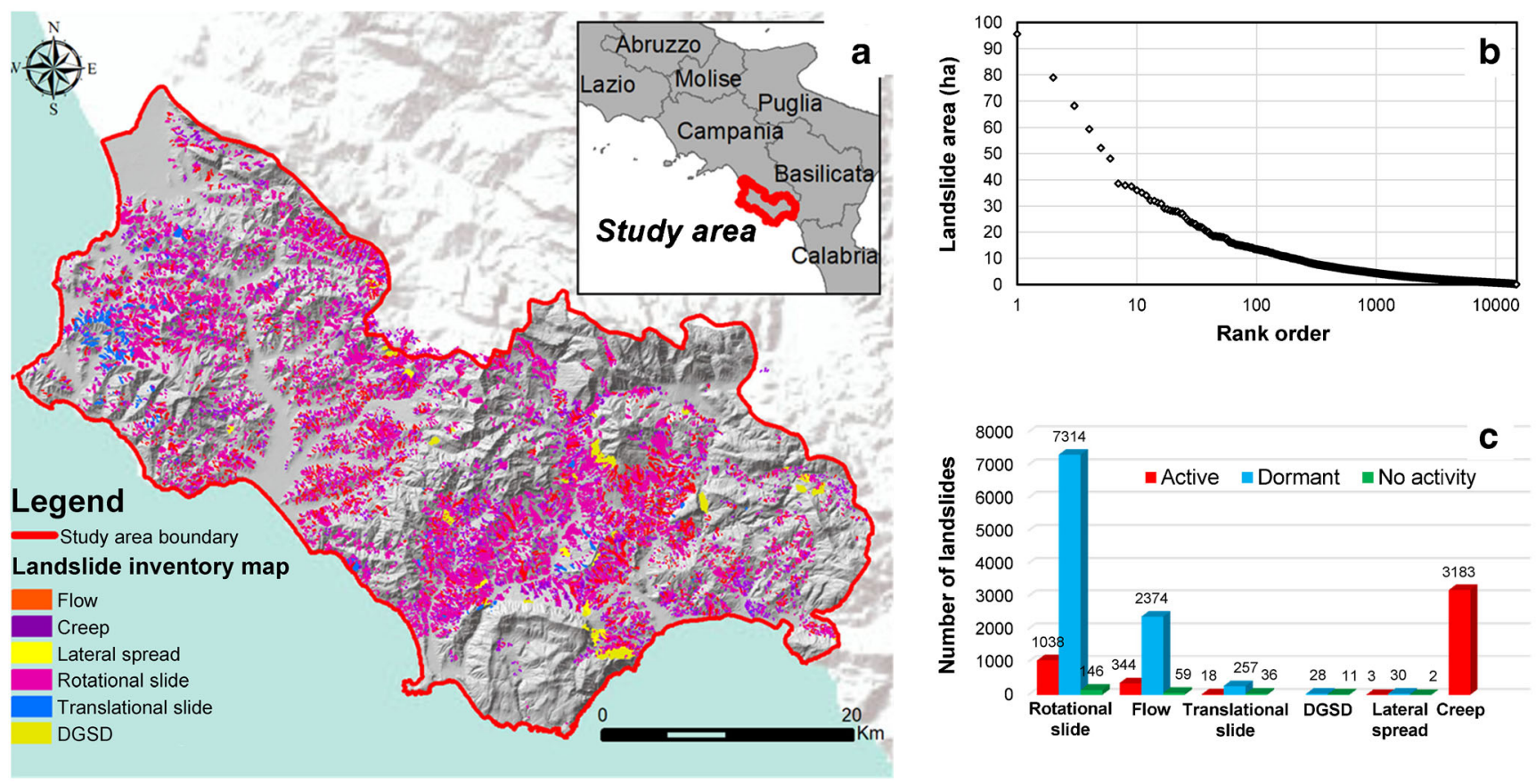

Fig. 6 a Inventory map of the slow-moving landslides within the study area, $\mathbf{b}$ rank order of the extent of affected areas, and $\mathbf{c}$ number of landslides per type/state of activity 


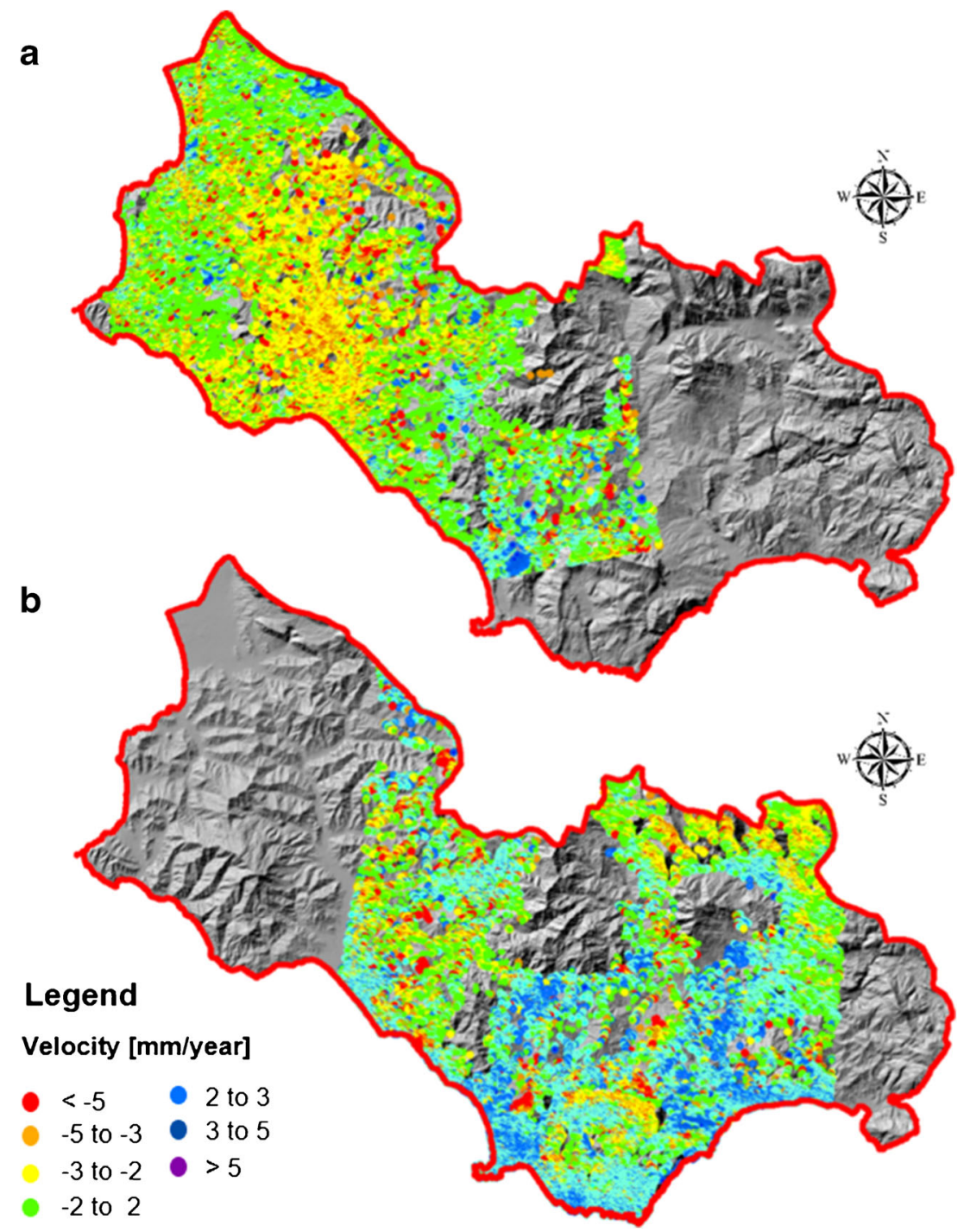

Fig. 7 Spatial distribution over the study area of PS (with associated average annual velocities along the LOS) obtained from COSMO-SkyMed images acquired on a ascending and $\mathbf{b}$ descending orbits

covered by COSMO-SkyMed data (ascending orbit) highlighting a displacement along the steepest slope direction of about $6 \mathrm{~cm}$ in about 3 years.

\section{Results}

According to the procedure shown in Fig. 1, by overlapping the landslide inventory map (Fig. 6a) with the graph of the road network (Fig. 5C), 549 road stretches were first identified and later surveyed (from March 2018 to July 2018) in order to detect the related damage and classify its severity. Among these stretches, 102 crossing urban centers were discarded because their damage was not straightforwardly attributable to landslide movements or had been caused by tilting/failure of the structures (e.g., walls, sheet piles) retaining the road embankment.

As far as the remaining 447 road stretches are concerned, a database including $X$ (486) road sections whose damage severity covers all the considered levels $\left(D_{0}=321, D_{1}=58, D_{2}=79, D_{3}=28\right)$ was generated (Fig. 9a). The damage mainly occurs in correspondence of road sections located on stretches intersecting the landslide body or their head, whereas few cases refer to stretches in correspondence of the landslide foot, mainly for damage severity levels ranging from $D_{1}$ to $D_{3}$ (Fig. 9b). Overall, referring to the position of the stretches with respect to the landslide-affected areas, the damage survey led to the following percentages of stretches that exhibit a damage severity exceeding or not exceeding the $\mathrm{D}_{\mathrm{o}}$ level: head ( $38.7 \%$ exceeding, $61.3 \%$ not exceeding); body (38.8\% exceeding, $61.2 \%$ not exceeding); foot ( $9.0 \%$ exceeding, $91.0 \%$ not exceeding).

A subset $\mathrm{x}$ (318) of $\mathrm{X}$ was not considered for analysis purposes on the basis of well-established criteria (e.g., road sections not covered by DInSAR data or for which DInSAR data interpretation was not reliable since, for instance, the scaling factor of the projection operation from LOS to the steepest slope direction exceeded the fixed threshold). 


\section{FACT-SHEET}

DATE: $2018 / 03 / 18$

\begin{tabular}{|c|l|c|c|}
\hline \multicolumn{3}{|c|}{ SECTION 1: Area and road stretch information } \\
\hline \multirow{2}{*}{ Region } & Campania & Road & former State road 267 \\
\hline \multirow{2}{*}{ Province } & Salerno & Coordinates & $40^{\circ} 10^{\prime} 17.9^{\prime \prime} \mathrm{N} 15^{\circ} 03^{\prime} 12.4^{\prime \prime} \mathrm{E}$ \\
\hline \multirow{2}{*}{ Municipality } & Pollica & Typology & Cut slope section \\
\hline
\end{tabular}
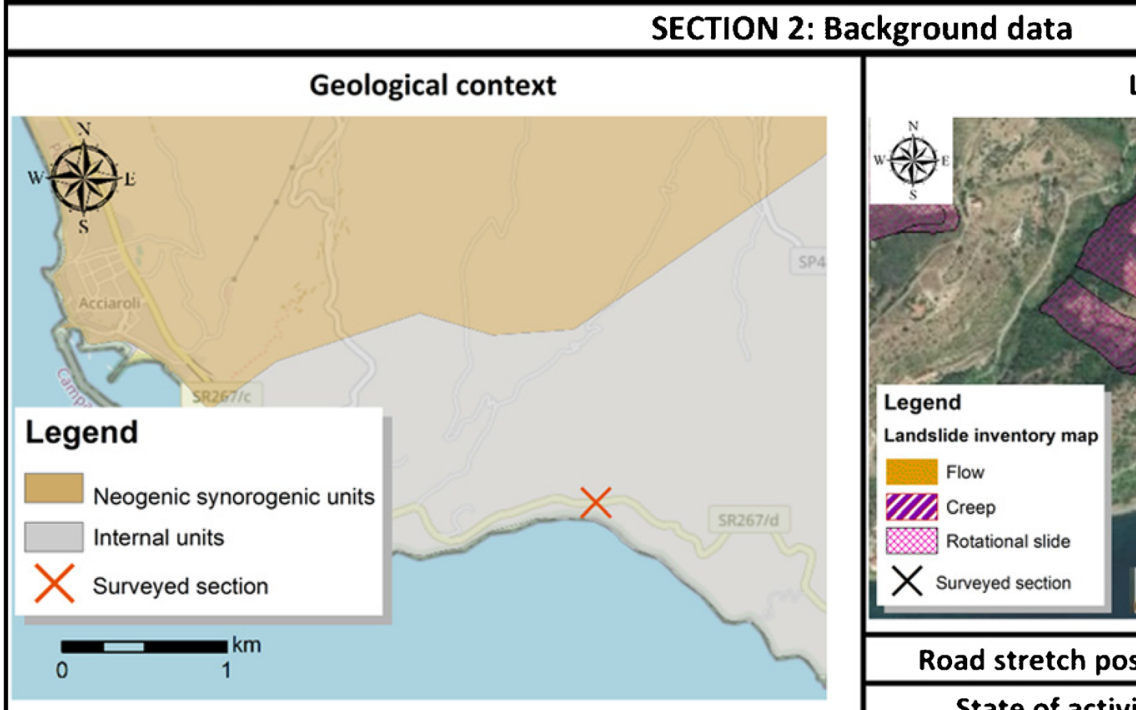

Landslide inventory map

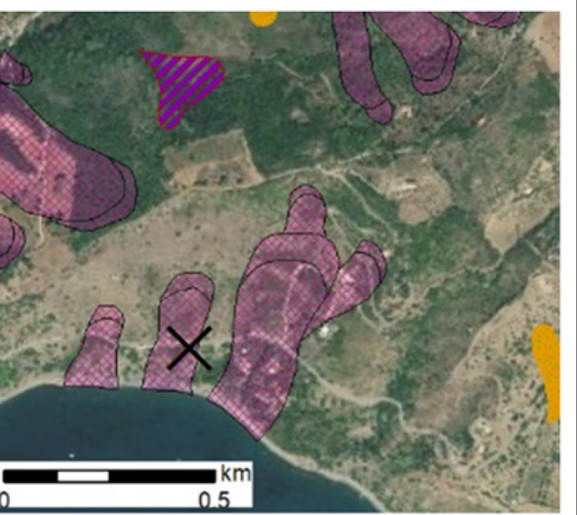

\begin{tabular}{|c|c|}
\hline Road stretch position & $\square$ Head $\square$ Body $\square$ Foot \\
\hline State of activity & Active $\square$ Dormant $\square$ Inactive \\
\hline
\end{tabular}
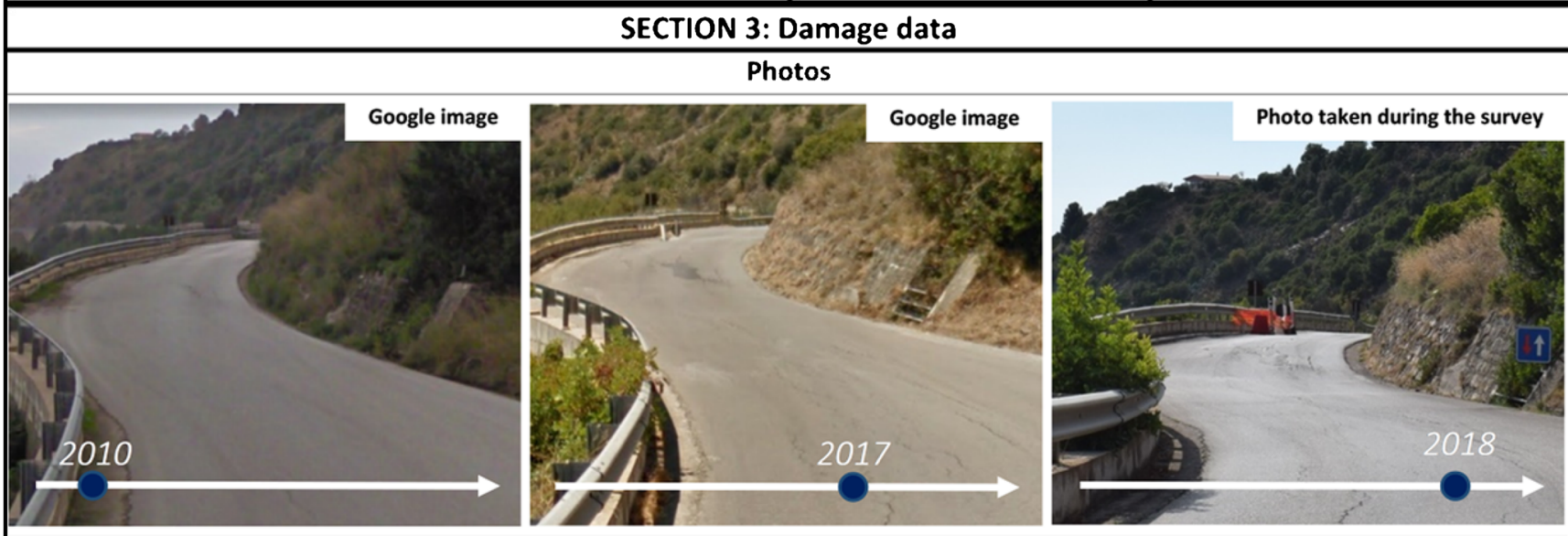

\begin{tabular}{|c|c|c|c|}
\hline \multicolumn{3}{|c|}{ Recorded damage } & SECT \\
\hline Category & Severity level & & \\
\hline$D_{0}$ & Negligible & 口 & \\
\hline $\mathrm{D}_{1}$ & From very low to low & 口 & 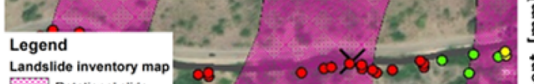 \\
\hline $\mathrm{D}_{2}$ & From moderate to severe & 口 & $\begin{array}{l}\text { PSI data } \\
\text { vslopo [mmiy] } \\
0<-5 \\
0.5\end{array}$ \\
\hline $\mathrm{D}_{3}$ & Very severe & 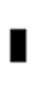 & $\begin{array}{l}0.3 \text { to }-2 \\
0.2 \text { to } 2 \\
X \text { surveyed section }\end{array}$ \\
\hline
\end{tabular}

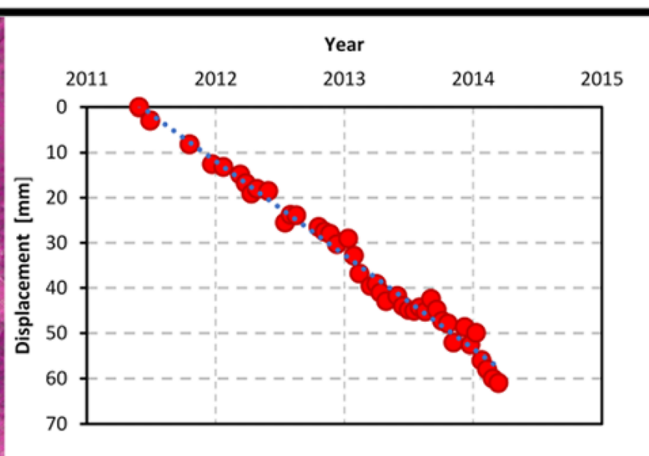

Fig. 8 An example of the fact-sheet used for road stretch damage surveying 

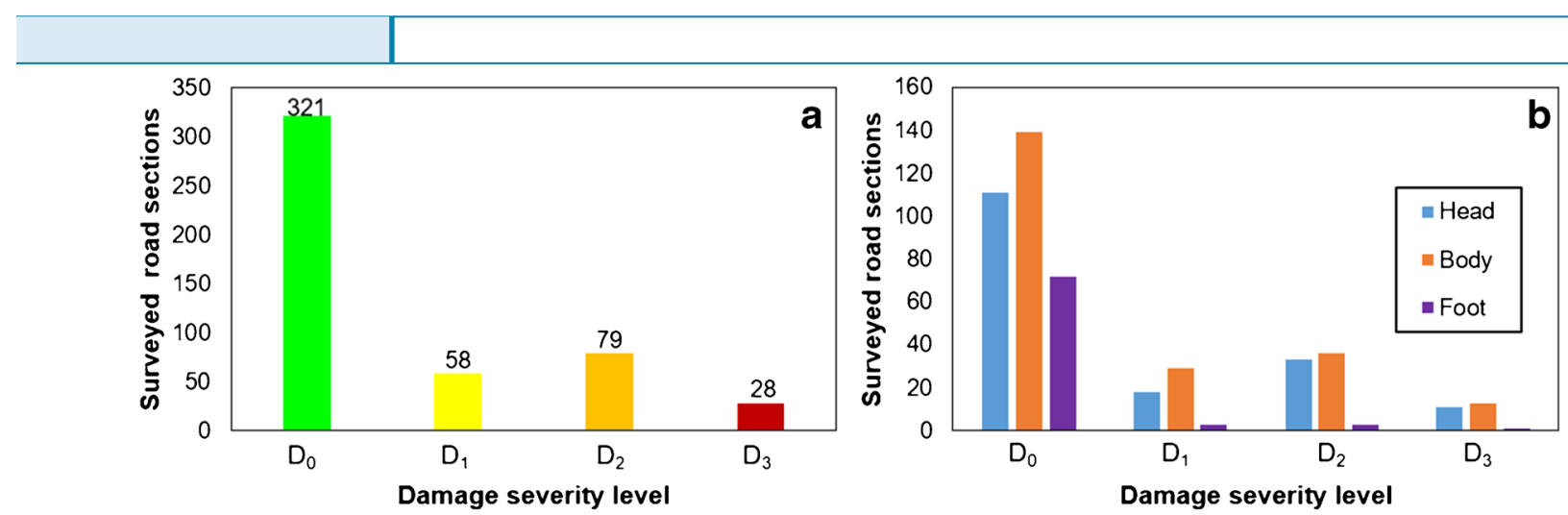

Fig. 9 Numerical distribution of the surveyed road sections a according to the recorded damage severity level and $\mathbf{b}$ taking into account the position of corresponding stretches with respect to the slow-moving-landslide-affected areas

The sample $\mathrm{Y}=\mathrm{X}-\mathrm{x}(168)$ includes road sections whose damage severity level $\left(D_{0}=67, D_{1}=29, D_{2}=48, D_{3}=24\right)$ can be associated with a value of IM. To this aim, given a road section (and the related buffer), the $\mathrm{V}_{\text {LOS_k }}$ velocity pertaining to each PS associated with the COSMO-SkyMed image dataset was first projected along the steepest slope direction according to Cascini et al. (2010, 2013); then, the $v_{\text {slope }}$ value was obtained by using the Eqs. (1a) and (1b).

Figure 10a shows that as $v_{\text {slope }}$ values, on average, increase the level of damage severity increases as well. This aspect is even clearer in Fig. 1ob where it can be noticed that the road sections

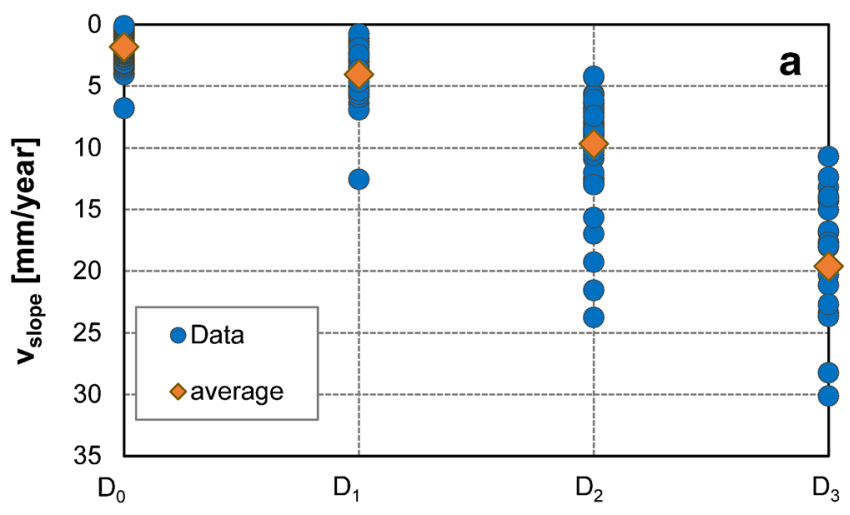

Damage severity level

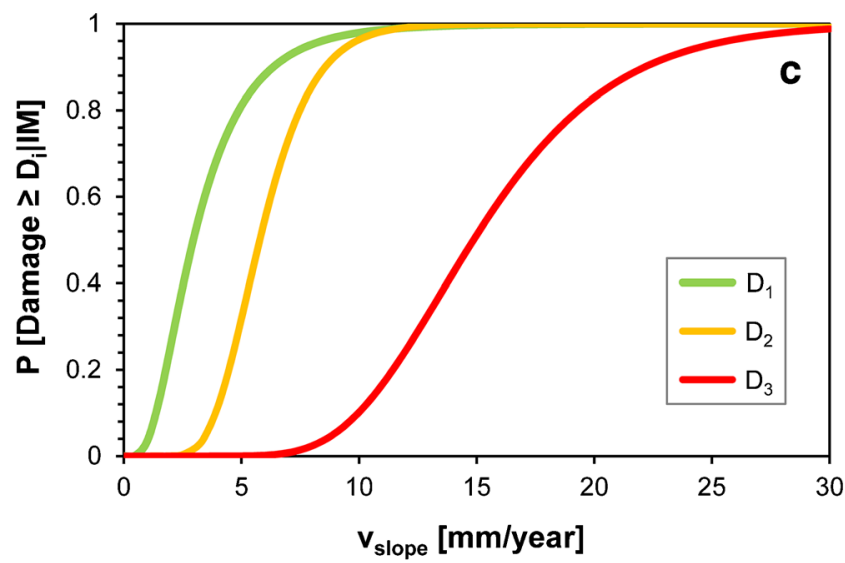

with (i) $D_{1}$ damage severity have $v_{\text {slope }}$ values mostly lower than $8 \mathrm{~mm} /$ year, (ii) $\mathrm{D}_{2}$ damage severity have $\mathrm{v}_{\text {slope }}$ values ranging from 4 to $24 \mathrm{~mm} /$ year, and (iii) $\mathrm{D}_{3}$ damage severity are associated with $\mathrm{v}_{\text {slope }}$ values ranging from 8 up to more than $32 \mathrm{~mm} /$ year.

Referring to the $\mathrm{Y}$ sample, the empirical fragility curves (Fig. 10c) and the vulnerability curve (Fig. 10d) were generated. As for the fragility curves, it is worth stressing that the one associated with the $D_{1}$ damage severity represents the probability that "at least a damage from very low to low" will be sustained by an exposed road section, arbitrarily chosen from the $\mathrm{Y}$ sample,
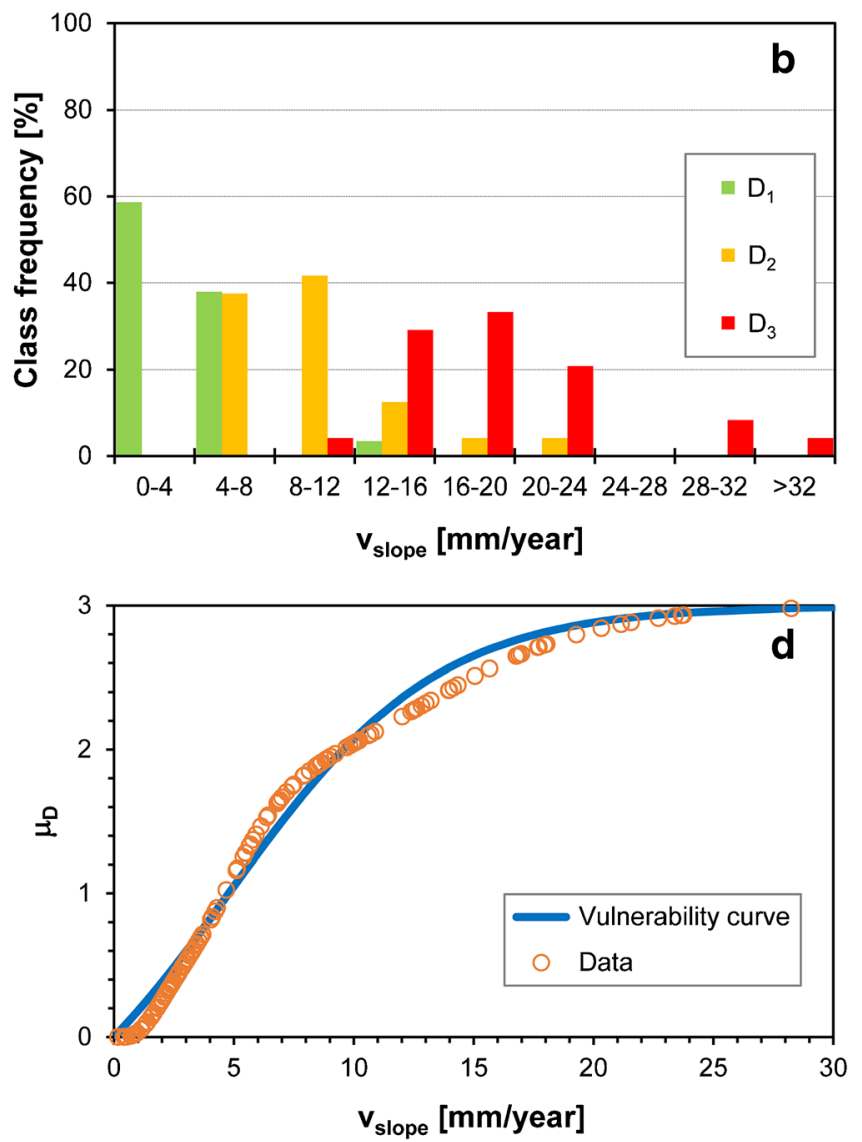

Fig. 10 a Damage severity level recorded to the surveyed road sections vs. $v_{\text {slope, }} \mathbf{b}$ class frequency of recorded damage severity levels according to $\mathrm{v}_{\text {slope, }} \mathbf{c}$ empirical fragility curves, and $\mathbf{d}$ empirical vulnerability curve 
Table 3 Median $\left(\overline{I M}_{i}\right)$ and dispersion $\left(\beta_{\mathrm{i}}\right)$ values of the log-normal distribution function, derived by way of the maximum likelihood estimation method, for each damage severity level

\begin{tabular}{|ccc|} 
Damage severity level & $\bar{M}_{i}(\mathrm{~mm} /$ year $)$ & $\beta_{\mathrm{i}}$ \\
\hline $\mathrm{D}_{1}$ & 2.96 & 0.60 \\
\hline $\mathrm{D}_{2}$ & 5.78 & 0.31 \\
\hline $\mathrm{D}_{3}$ & 14.87 & 0.31 \\
\hline
\end{tabular}

when subjected to a given $\mathrm{v}_{\text {slope }}$ value; the same meaning applies to other fragility curves (Shinozuka et al. 2000). Figure 10c shows that up to $\mathrm{v}_{\text {slope }}$ values of about $10 \mathrm{~mm} /$ year the probabilities of reaching or exceeding $\mathrm{D}_{1}$ or $\mathrm{D}_{2}$ are both over $90 \%$ whereas $\mathrm{D}_{3}$ does not exceed $10 \%$. The latter reaches the highest probabilities for $\mathrm{v}_{\text {slope }}$ values of about $30 \mathrm{~mm} /$ year. Table 3 shows the values of the fragility parameters. Based on the vulnerability curve (Fig. 10d), it can be observed that $\mathrm{v}_{\text {slope }}$ values of about 5,10 , and $30 \mathrm{~mm} /$ year can be associated with numerical indices of the average damage expected to the road sections $\left(\mu_{D}\right)$ equalling 1,2 , and 3 respectively. The computed values of the coefficients of the vulnerability curve are summarized in Table 4.

The fragility curves allowed retrieving the threshold values $\left(\mathrm{T}_{\mathrm{i}}\right)$ of IM, here assumed as the values of IM in correspondence of $5 \%$ probability of reaching/exceeding a given damage severity level; accordingly, we obtained: $\mathrm{T}_{1}=1.1 \mathrm{~mm} /$ year; $\mathrm{T}_{2}=3.5 \mathrm{~mm} /$ year; $\mathrm{T}_{3}=$ $8.9 \mathrm{~mm} /$ year. Therefore, four different intensity levels were defined (see also table in Fig. 11). Then, the probabilistic analysis of the IM values used for the generation of the fragility curves was carried out. The distribution law that best fits the available data (Fig. 11a) is the negative exponential one (Fig. 11b). As shown in Fig. 11c, the values of $\mathrm{P}_{(\mathrm{SML}), \mathrm{d}}(\mathrm{d}=0, \ldots, 3)$ pertaining to each intensity level can be easily obtained on the basis of the cumulative distribution function of the random variable IM.

The next step dealt with the generation of the curve relating the expected average damage $\left(\mu_{D}\right)$ with the relative repair cost (RRC). To this aim, we used the price list provided by the "Ente Nazionale per le Strade" (ANAS 2018a, b) which allowed us to retrieve the repair costs (to be associated with $\mu_{\mathrm{D}}$ equalling 0,1 and 2), and the reconstruction cost (to be associated with $\mu_{\mathrm{D}}$ equalling 3 ) per unit road length $(1 \mathrm{~m})$. These costs are synthesized in Table 5 along with the corresponding RRC values, whereas Fig. 12 shows the obtained $\mu_{D}$-RRC curve. For the sake of simplicity, this curve was assumed as time-independent; this means that all cost items listed in the third column of Table 5 increase (or decrease) by the same rate with time.

Based on the $\mu_{D}$-RRC curve, $R R C_{d, \text { min }}$ and $R R C_{d, \max }(d=0, \ldots$, 3 ) values were estimated provided that corresponding $\mu_{D \_d, m i n}$ and $\mu_{\mathrm{D} \_\mathrm{d} \text {,max }}(\mathrm{d}=\mathrm{o}, \ldots, 3)$ values had been previously determined by way of the vulnerability curve, for a given intensity level. The obtained values are synthesized in Table 6 .

Table 4 Coefficients of the empirical vulnerability curve

\begin{tabular}{llll}
$C_{1}$ & $C_{2}$ & $C_{3}$ & $C_{4}$ \\
2.00 & 0.50 & 0.11 & -0.55 \\
\hline
\end{tabular}

Focusing on the 24 road sections recording a $\mathrm{D}_{3}$ severity level based on the damage survey, the availability of antecedent Google Street View images allowed us to retrieve the reference time $t^{*}$ (equalling 7.4 years) by averaging the time required by each of the above road sections to move from $\mathrm{D}_{\mathrm{o}}$ (if any) to $\mathrm{D}_{3}$. In this regard, 10 road sections out of 24 exhibited the full development of damage within the observation period. Then, the $\mathrm{UC}^{\star}$ value (equalling $€$ 254.94) was computed according to Eq. (8) by applying a nominal annual interest rate whose percentage value equals $1.56 \%$ on the basis of data provided by the Italian Institute for Statistics (ISTAT 2019) about the change in construction costs of roads over time (from 2005 to 2017); on the other hand, $\mathrm{UC}_{\mathrm{o}}$ was posed equal to the unit cost at the time when the damage survey was carried out, which can be computed on the basis of the price list of ANAS $\left(2018 \mathrm{a}, \mathrm{b}\right.$ ) so obtaining $\mathrm{UC}_{\mathrm{o}}=€ 227.35$ (see also Table 5).

Finally, according to Eqs. (7a) and ( $7 \mathrm{~b})$, the risk was estimated; in particular, it ranges between a minimum $\left(\mathrm{R}_{(\mathrm{RN}), \mathrm{min}}\right)$ and a maximum $\left(\mathrm{R}_{(\mathrm{RN}) \text {,max }}\right)$ value equalling respectively:

$\mathrm{R}_{(\mathrm{RN}), \min }=€ 981,133$

$\mathrm{R}_{(\mathrm{RN}), \max }=€ 2,338,276$

To carry out the quantitative consequence analysis (QCA) with reference to the road network under consideration (which is already damaged) in a time $t$ greater than $t^{*}$, we proceeded based on the framework shown in Fig. 4.

The "actual" relative repair cost $\left(\mathrm{RRC}_{\mathrm{actual}}\right)$ was calculated by using Eq. (9), taking into account the entire sample (X) of road sections. In particular, the obtained value of $\mathrm{RRC}_{\text {actual }}$ (equal to 0.178 ) was estimated considering the total length of buffers distinguished according to the recorded damage severity level (Table 7).

Based on the curve shown in Fig. 12, a $\mu_{\mathrm{D}}$, actual equalling 1.02 was obtained in correspondence of the computed value of $\mathrm{RRC}_{\text {actual; }}$ then, the vulnerability curve (Fig. 10d) allowed us to retrieve a $v_{\text {slope, actual }}=4.9 \mathrm{~mm} /$ year associated with $\mu_{\mathrm{D} \text {, actual }}$.

Assuming a forecasting time interval $\Delta \mathrm{t}=\mathrm{t}-\mathrm{t}^{*}=5$ years, for example, the average cumulative displacement of the slow-moving landslide bodies expected during this $\Delta \mathrm{t}$ equalled $\Delta \mathrm{s}=\mathrm{v}_{\text {slope, actual }}$ $\times \Delta \mathrm{t}=24.5 \mathrm{~mm}$; on the other hand, $\mathrm{s}=\mathrm{v}_{\text {slope,actual }} \times \mathrm{t}^{*}=36.2 \mathrm{~mm}$.

Once the parameters $s$ and $\Delta s$ were known, it was stated that, in order to have at the time $t^{\star}$ an average cumulative displacement $\mathrm{s}+\Delta \mathrm{s}$, the average $\mathrm{v}_{\text {slope }}$ must be equal to $\mathrm{v}_{1}=(\mathrm{s}+\Delta \mathrm{s}) / \mathrm{t}^{*}=$ $8.2 \mathrm{~mm} /$ year. In turn, $\mathrm{v}_{1}$ allowed us to estimate - based on the vulnerability curve - the value of the expected average damage at the time $t=t^{*}+\Delta t=12.4$ years; in particular, $\mu_{D}$, actual $+\Delta t=1.75$.

The latter value was introduced again into the curve of Fig. 12 to retrieve the value of $R_{R C}$ actual $+\Delta t=0.417$ from which, by subtracting the $\mathrm{RRC}_{\text {actual }}$ value, the increment of $\mathrm{RRC}$ from $\mathrm{t}^{*}$ to $\mathrm{t}(\triangle \mathrm{RRC})$ was finally obtained:

$\Delta \mathrm{RRC}=\mathrm{RRC}_{\mathrm{actual}+\Delta \mathrm{t}}-\mathrm{RRC}_{\mathrm{actual}}=0.239$

Based on the above presented analytical steps and taking account of the methodological details provided in the sub-section entitled "Quantitative consequence analysis," $\mu_{D}$ was estimated for 

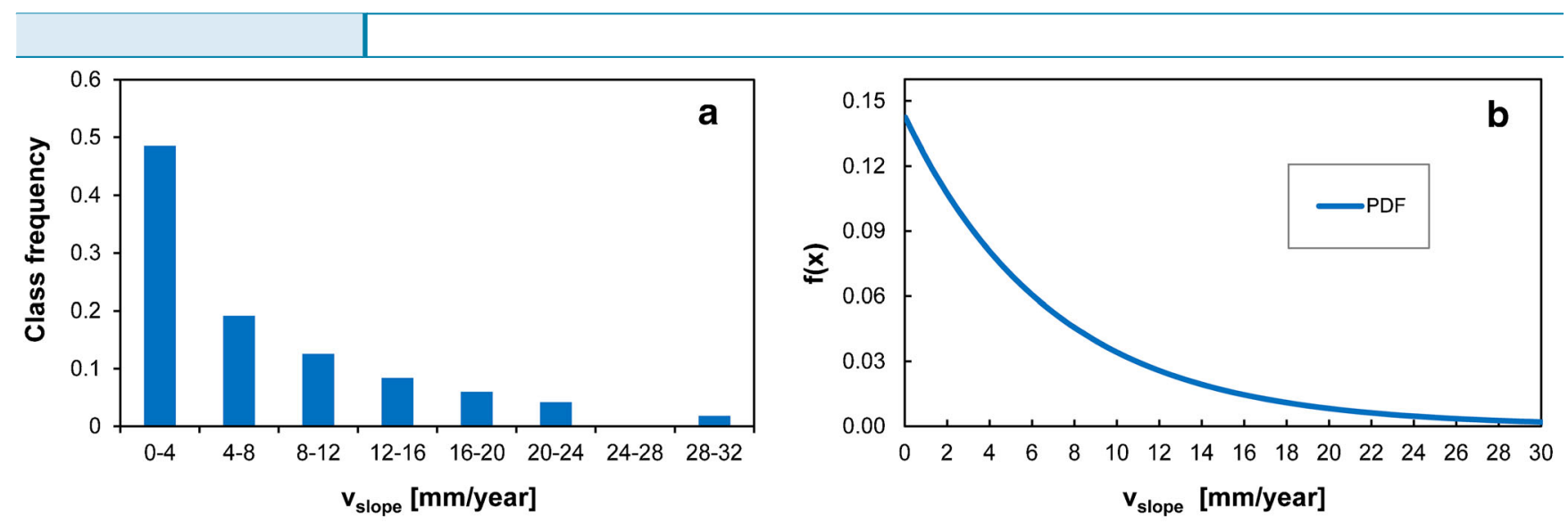

\begin{tabular}{cc}
\hline Intensity level [mm/year] & $\mathbf{P}_{\text {(SML),d }}$ \\
\hline $0<\mathrm{v}_{\text {slope }} \leq 1.1$ & 0.14 \\
\hline $1.1<\mathrm{v}_{\text {slope }} \leq 3.5$ & 0.25 \\
\hline $3.5<\mathrm{v}_{\text {slope }} \leq 8.9$ & 0.33 \\
\hline $\mathrm{v}_{\text {slope }}>8.9$ & 0.28 \\
\hline
\end{tabular}

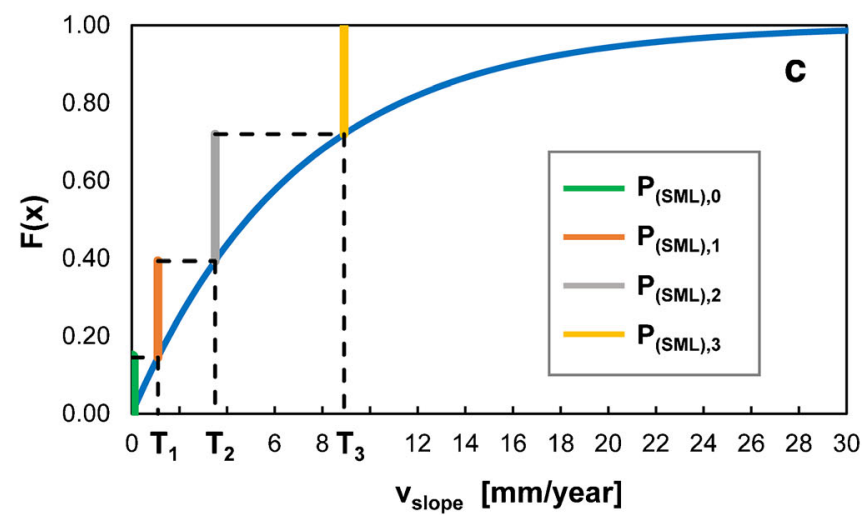

Fig. 11 a Class frequency, $\mathbf{b}$ probability density function (PDF), and $\mathbf{c}$ cumulative distribution function (CDF) of $\mathrm{v}_{\text {slope }}$. The probabilities of occurrence of slow-moving landslides of a given intensity level are summarized in the included table

different time periods greater than $t^{\star}$. In this regard, Fig. 13 shows the vulnerability curves obtained with reference to four time periods, including the one associated with $t^{*}$. These curves allow highlighting how the vulnerability of the road network increases as cumulative displacements of interacting slow-moving landslides (and the induced road damage) increase. For instance, considering a $v_{\text {slope }}$ value equal to $v_{\text {slope, actual }}(4.9 \mathrm{~mm} /$ year $)$, the $\mu_{D}$ value progressively moves from 1.02 (at $t^{\star}=7.4$ years) to 1.75 (at $t^{\star}+$ 5 years) or to 2.30 (at $t^{\star}+10$ years) or to 2.64 (at $t^{\star}+15$ years).

Discussion and conclusions

This paper showed the results of a study aimed at quantitatively estimating - at large scale (1:500o) - the risk (QRA)/direct consequences (QCA) to an undamaged/damaged road network exposed

Table 5 Activities required for the repair of roads suffering from damage of different severity (marked with an X) and related costs

\begin{tabular}{|c|c|c|c|c|c|c|}
\hline Activity & Unit of measure & Cost [€] & \multicolumn{2}{|c|}{$\begin{array}{l}\text { Damage severity level } \\
D_{0} \quad D_{1}\end{array}$} & $D_{2}$ & $D_{3}$ \\
\hline Sealing of cracks in the road pavement & $\mathrm{m}$ & 3.99 & $x$ & - & - & - \\
\hline $\begin{array}{l}\text { Supply and installation of asphalt concrete for } \\
\text { wear layer }(4 \mathrm{~cm} \text { thick) }\end{array}$ & $\mathrm{m}^{3}$ & 137.86 & - & $x$ & $\mathrm{X}$ & $x$ \\
\hline Milling of pavement layers made of asphalt concrete & $\mathrm{m}^{2} \times \mathrm{cm}$ & 0.42 & - & - & $\mathrm{X}$ & $X$ \\
\hline $\begin{array}{l}\text { Supply and installation of asphalt concrete } \\
\text { for binder layer ( } 5 \mathrm{~cm} \text { thick) }\end{array}$ & $\mathrm{m}^{3}$ & 125.61 & - & - & $\mathrm{X}$ & $X$ \\
\hline $\begin{array}{l}\text { Supply and spraying of bitumen modified } \\
\text { with elastomers }\end{array}$ & $\mathrm{m}^{2}$ & 0.71 & - & - & $X$ & $X$ \\
\hline $\begin{array}{l}\text { Supply and installation of asphalt concrete } \\
\text { for base layer }(8 \mathrm{~cm} \text { thick) }\end{array}$ & $\mathrm{m}^{3}$ & 115.44 & - & - & - & $X$ \\
\hline $\begin{array}{l}\text { Supply and installation of the road foundation } \\
\text { made of stabilized granular mixture }(15 \mathrm{~cm} \text { thick) }\end{array}$ & $\mathrm{m}^{3}$ & 19.26 & - & - & - & $X$ \\
\hline Repair unitary cost $[€ / \mathrm{m}]$ & & & 3.99 & 38.60 & 113.99 & 227.35 \\
\hline Relative repair cost (RRC) & & & 0.0175 & 0.1698 & 0.5014 & 1 \\
\hline
\end{tabular}

Thickness of different layers refers to secondary suburban roads according to Domenichini et al. (1993); the road width was posed equal to $7 \mathrm{~m}$ 


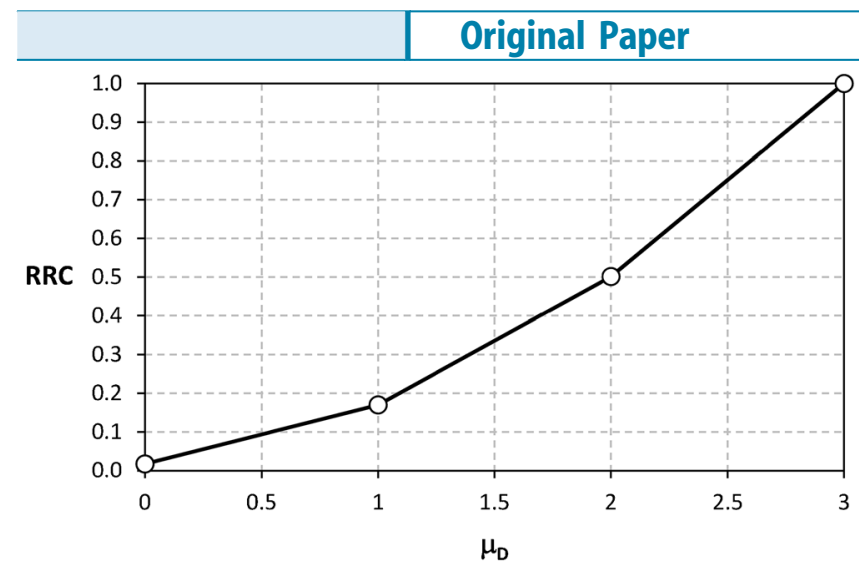

Fig. 12 Expected average damage $\left(\mu_{D}\right)$ vs. relative repair cost (RRC)

to slow-moving landslides. With reference to a case study in the Campania region (southern Italy), the analyses benefited from the availability of very high-resolution DInSAR data and information gathered from in situ surveys on the severity of damage to selected road sections. The proposed methodological approaches allowed us to successfully address some open issues in the scientific literature concerning the hazard analysis (e.g., in terms of probability of occurrence of slow-moving landslides with a given intensity level, in turn established based on empirical fragility curves) and the consequence analysis (e.g., in terms of time-dependence of the vulnerability curves).

The QRA results were expressed in terms of repair costs (in $€$ ) ranging between a minimum and a maximum value, to be referred to the average time required for the full development of damage in at least one road section. The obtained range of risk values takes into account the high degree of uncertainty that, at large scale, affects the QRA. In this regard, uncertainties can be associated with the errors inherent to slow-moving landslide mapping, the subjective nature of the road damage severity assessment (which is based on the judgment of the expert carrying out the in situ surveys or interpreting the Google Street View images), the lack of knowledge on precise values of cumulative displacements required for road sections interacting with slow-moving landslides to move from a damage severity level to the next one, the unavailability of DInSAR data in both ascending and descending orbits, the variability of mechanical characteristics of materials forming the roads from one exposed section to another. Anyway, the QRA results can be profitably used for risk management purposes. For instance, the potentially involved decision-makers could decide that the risk-to which the road network under study is exposed-has to be mitigated by reducing the hazard of the DInSAR-covered road sections associated with a high-intensity
Table 7 Total length of buffers distinguished according to the recorded damage severity level

\begin{tabular}{rr}
\hline$D_{0}$ & 37,781 \\
\hline$D_{1}$ & 7377 \\
\hline$D_{2}$ & 10,775 \\
\hline$D_{3}$ & 3204 \\
\hline
\end{tabular}

level, independently of the recorded damage severity, by way of slope stabilization works. In particular, the latter should be designed on the basis of a performance-based approach that involves immediately limiting IM to values not exceeding the $\mathrm{T}_{1}$ threshold (1.1 mm/year), which then remain constant over a certain time period (e.g., 30 years, corresponding to the nominal life of interventions). Should all damaged road sections have been repaired, the use of Eqs. ( $7 \mathrm{a})$ and ( $7 \mathrm{~b})$ allows one to obtain maximum and minimum residual risk values respectively equalling $€ 753,147$ and $€ 233,255$ (keeping fixed the intensity threshold values and posing $\left.\mathrm{P}_{(\mathrm{SML}), 3}=\mathrm{o}\right)$. Accordingly, the implementation of the above risk mitigation strategy could allow for a reduction of risk (from preto post-interventions) equalling $67.8 \%$ (for the maximum value) and $76.2 \%$ (for the minimum value).

On the other hand, if the decision about the risk mitigation is postponed, the methodological approach adopted for QCA can turn out to be useful. For instance, looking at Fig. 13, the potentially involved decision-makers could decide to wait 5 years before implementing the interventions (or, similarly, 5 years after 2018, when damage surveys were carried out). This would imply that the reconstruction cost of all exposed road stretches (whose total length equals 59,137 m) moves from $€$ 13,445,016 (when UC $=€$ 227.35) to $€ 14,526,736$ (when UC $=€ 245.65$, taking account of the nominal annual interest rate). Since $\mu_{\mathrm{D}}$ increases from 1.02 to 1.75 in 5 years-and, accordingly, the RRC from 0.178 to 0.417 - the repair cost of the road network would change from $€ 2,392,234$ to $€ 6,058,039$ with a percentage increase equalling the $153.2 \%$.

Of course, the above decisions on whether and when a risk mitigation strategy has to be implemented requires carrying out a wider study including the quantification of the indirect (social and economic) consequences associated with the slow-moving landslide-induced road damage. This could allow also for the vehicular traffic control before and during the implementation of interventions. However, estimating indirect consequences is beyond the scope of this paper.

Further refinements of the work done deal with carrying out QRA/QCA at a detailed scale ( $>$ 1:5000), provided that more accurate data (both in quality and quantity) are collected for single

Table 6 Values of pairs $\mu_{D \_d \text {,min }}-R R C_{d, \text { min }}$ and $\mu_{D_{-} d \text {,max }}-R R C_{d, \text { max }}(d=0, \ldots, 3)$ for each intensity level Intensity level (mm/year) From the vulnerability curve, Fig. From the $\mu_{D}-R R C$ curve, Fig.

\begin{tabular}{|c|c|c|c|c|c|c|c|c|}
\hline $0<v_{\text {slope }} \leq 1.1$ & $\mu_{D_{-} 0, \text { min }}$ & - & $\mu_{D \_0, \max }$ & 0.203 & $\mathrm{RRC}_{0, \text { min }}$ & 0.0175 & $\mathrm{RRC}_{0, \text { max }}$ & 0.0484 \\
\hline $1.1<\mathrm{v}_{\text {slope }} \leq 3.5$ & $\mu_{D_{-} \_1 \text { min }}$ & 0.203 & $\mu_{D \_1, \max }$ & 0.705 & $\mathrm{RRC}_{1, \min }$ & 0.0484 & $\mathrm{RRC}_{1, \max }$ & 0.1248 \\
\hline $3.5<\mathrm{v}_{\text {slope }} \leq 8.9$ & $\mu_{\mathrm{D} \_ \text {2,min }}$ & 0.705 & $\mu_{D \_2, \max }$ & 1.882 & $\mathrm{RRC}_{2, \min }$ & 0.1248 & $\mathrm{RRC}_{2, \max }$ & 0.4624 \\
\hline $\mathrm{v}_{\text {slope }}>8.9$ & $\mu_{D \_3, \min }$ & 1.882 & $\mu_{D \_3, \max }$ & - & $\mathrm{RRC}_{3, \min }$ & 0.4624 & $\mathrm{RRC}_{3, \max }$ & 1 \\
\hline
\end{tabular}




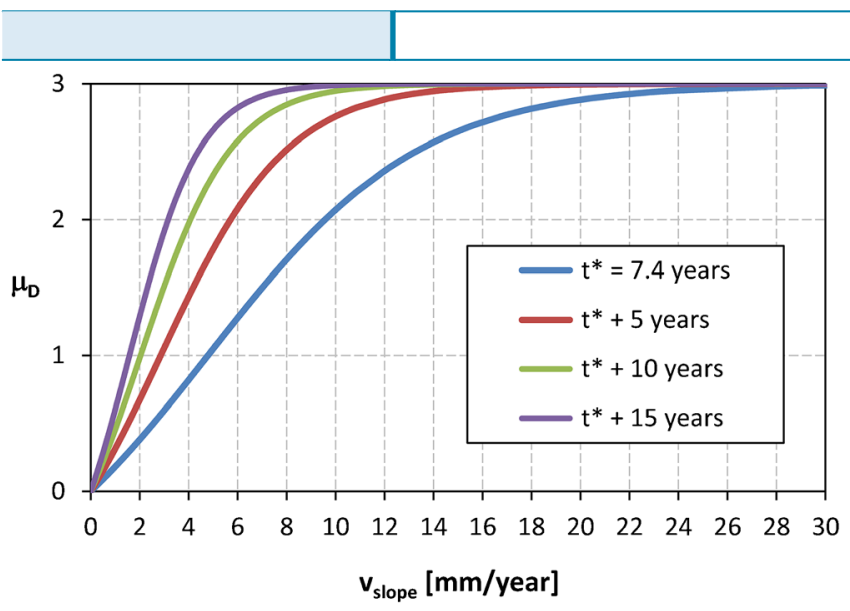

Fig. 13 Vulnerability curves referring to four periods

slow-moving landslides and affected road stretches. This could lead to the prioritization of risk mitigation measures and their proper choice/design.

Finally, it is worth mentioning the potential exportability of both the proposed methodological approaches and the obtained results (i.e., fragility/vulnerability curves) that, once further validated, could stand as a reference for QRA/QCA concerning other similar road networks in similar geo-environmental contexts that are widespread in southern Italy.

\section{Acknowledgments}

The processed DInSAR data were provided by the Italian Ministry of the Environment and Protection of Land and Sea within the nationwide Italian "Piano Straordinario di Telerilevamento". The authors wish to thank the editor and two anonymous reviewers who helped improve the paper in its revised version.

\section{Funding Information}

Open access funding provided by Università degli Studi di Salerno within the CRUI-CARE Agreement.

Open Access This article is licensed under a Creative Commons Attribution 4.0 International License, which permits use, sharing, adaptation, distribution and reproduction in any medium or format, as long as you give appropriate credit to the original author(s) and the source, provide a link to the Creative Commons licence, and indicate if changes were made. The images or other third party material in this article are included in the article's Creative Commons licence, unless indicated otherwise in a credit line to the material. If material is not included in the article's Creative Commons licence and your intended use is not permitted by statutory regulation or exceeds the permitted use, you will need to obtain permission directly from the copyright holder. To view a copy of this licence, visit http://creativecommons.org/licenses/by/ 4.0/.

\section{References}

ANAS (2018a) Listino prezzi 2018. Manutenzione Ordinaria. Ente Nazionale per le Strade (ANAS), Rome, $83 \mathrm{pp}$ (in Italian)

ANAS (2018b) Listino prezzi 2018. Nuove Costruzioni, Manutenzione Straordinaria. Ente Nazionale per le Strade (ANAS), Rome, $291 \mathrm{pp}$ (in Italian)

Antronico L, Borrelli L, Coscarelli R, Pasqua AA, Petrucci O, Gullà G (2013) Slope movements induced by rainfalls damaging an urban area: the Catanzaro case study (Calabria, southern Italy). Landslides 10(6):801-814. https://doi.org/10.1007/s10346013-0431-3

Argyroudis SA, Mitoulis SA, Winter MG, Kaynia AM (2019) Fragility of transport assets exposed to multiple hazards: state-of-the-art review toward infrastructural resilience. Reliab Eng Syst Saf. https://doi.org/10.1016/j.ress.2019.106567

Bianchini S, Cigna F, Righini G, Proietti C, Casagli N (2012) Landslide hotspot mapping by means of persistent scatterer interferometry. Environ Earth Sci 67:1155-1172. https:// doi.org/10.1007/s12665-012-1559-5

Bianchini S, Herrera G, Mateos RM, Notti D, Garcia I, Mora 0, Moretti S (2013) Landslide activity maps generation by means of persistent scatterer interferometry. Remote Sens 5(12):6198-6222. https://doi.org/10.3390/rs5126198

Bianchini S, Ciampalini A, Raspini F, Bardi F, Di Traglia F, Moretti S, Casagli N (2015) Multi-temporal evaluation of landslide movements and impacts on buildings in San Fratello (Italy) by means of C-Band and X-Band PSI data. Pure Appl Geophys 172:3043-3065. https://doi.org/10.1007/s00024-014-0839-2

Budetta P (2002) Risk assessment from debris flows in pyroclastic deposits along a motorway, Italy. Bull Eng Geol Environ 61(4):293-301. https://doi.org/10.1007/ s10064-002-0161-6

Budetta P (2004) Assessment of rockfall risk along roads. Nat Hazards Earth Syst Sci 4(1):71-81. https://doi.org/10.5194/nhess-4-71-2004

Budetta P, Nappi M (2013) Comparison between qualitative rockfall risk rating systems for a road affected by high traffic intensity. Nat Hazards Earth Syst Sci 13(6):16431653. https://doi.org/10.5194/nhess-13-1643-2013

Budetta P, De Luca C, Nappi M (2016) Quantitative rockfall risk assessment for an important road by means of the rockfall risk management (RO.MA.) method. Bull Eng Geol Environ 75(4):1377-1397. https://doi.org/10.1007/s10064-015-0798-6

Bunce CM, Cruden DM, Morgenstern NR (1997) Assessment of the hazard from rock fall on a highway. Can Geotech J 34(3):344-356. https://doi.org/10.1139/t97-009

Calvello M, Peduto D, Arena L (2017) Combined use of statistical and DInSAR data analyses to define the state of activity of slow-moving landslides. Landslides 14(2):473-489. https://doi.org/10.1007/s10346-016-0722-6

Cascini L, Fornaro G, Peduto D (2010) Advanced low-and full-resolution DInSAR map generation for slow-moving landslide analysis at different scales. Eng Geol 112(14):29-42. https://doi.org/10.1016/j.enggeo.2010.01.003

Cascini L, Peduto D, Pisciotta G, Arena L, Ferlisi S, Fornaro G (2013) The combination of DInSAR and facility damage data for the updating of slow-moving landslide inventory maps at medium scale. Nat Hazards Earth Syst Sci 13(6):1527-1549. https://doi.org/ 10.5194/nhess-13-1527-2013

Castaldo R, Tizzani P, Calò F, Ardizzone F, Lanari R, Guzzetti F, Manunta M (2015) Landslide kinematical analysis through inverse numerical modelling and differential SAR interferometry. Pure Appl Geophys 172(11):3067-3080. https://doi.org/10.1007/ s00024-014-1008-3

Catani F, Casagli N, Ermini L, Righini G, Menduni G (2005) Landslide hazard and risk mapping at catchment scale in the Arno River basin. Landslides 2(4):329-342. https:// doi.org/10.1007/s10346-005-0021-0

Cigna F, Bianchini S, Casagli N (2013) How to assess landslide activity and intensity with persistent scatterer interferometry (PSI): the PSI-based matrix approach. Landslides 10(3):267-283. https://doi.org/10.1007/s10346-012-0335-7

Colesanti C, Wasowski J (2006) Investigating landslides with space-borne synthetic aperture radar (SAR) interferometry. Eng Geol 88(3-4):173-199. https://doi.org/ 10.1016/j.enggeo.2006.09.013

Corominas J, van Westen C, Frattini P, Cascini L, Malet J-P, Fotopoulou S, Catani F, Van Den Eeckhaut M, Mavrouli 0, Agliardi F, Pitilakis K, Winter MG, Pastor M, Ferlisi S, Tofani V, Hervàs J, Smith JT (2014) Recommendations for the quantitative analysis of landslide risk. Bull Eng Geol Environ 73(2):209-263. https://doi.org/10.1007/s10064013-0538-8

Costantini M, Falco S, Malvarosa F, Minati F (2008) A new method for identification and analysis of persistent scatterers in series of SAR images. IEEE International Geoscience \& Remote Sensing Symposium, July 6-11, 2008, Boston, Massachusetts, USA, pp 449-452. https://doi.org/10.1109//GARSS.2008.4779025

Crosetto M, Copons R, Cuevas-González M, Devanthéry N, Monserrat 0 (2018) Monitoring soil creep landsliding in an urban area using persistent scatterer interferometry (EI Papiol, Catalonia, Spain). Landslides 15(7):1317-1329. https://doi.org/10.1007/ s10346-018-0965-5

Cruden DM, Varnes DJ (1996) Landslide types and processes. In: Turner AK, Schuster RL (eds), Landslides investigation and mitigation. Transportation research board, US National Research Council, Washington DC, Special Report 247, Chapter 3, pp 36-75 
Di Maio C, Fornaro G, Gioia D, Reale D, Schiattarella M, Vassallo R (2018) In situ and satellite long-term monitoring of the Latronico landslide, Italy: displacement evolution, damage to buildings, and effectiveness of remedial works. Eng Geol 245:218235. https://doi.org/10.1016/j.enggeo.2018.08.017

Domenichini L, Di Mascio P, Giannattasio P, Caliendo C, Festa B, Marchionna A, Finni P, Molinaro E, Paoloni G (1993) Modello di catalogo delle pavimentazioni stradali. Fondazione Politecnica per il Mezzogiorno d'Italia, Naples 44 pp (in Italian)

Escario MV, George L, Cheney RS, Yamamura K (1997) Landslides - techniques for evaluating hazard. PIARC Technical Committee on Earthworks, Drainage and Subgrade, $117 \mathrm{pp}$

Fell R, Ho KKS, Lacasse S, Leroi E (2005) A framework for landslide risk assessment and management. In: Hungr 0 , Fell $R$, Couture $R$, Eberhardt $E$ (eds) Landslide risk management. Taylor and Francis, London, pp 3-26

Fell R, Corominas J, Bonnard C, Cascini L, Leroi E, Savage WZ (2008) Guidelines for landslide susceptibility, hazard and risk zoning for land-use planning. Eng Geol 102(3-4):99-111. https://doi.org/10.1016/j.enggeo.2008.03.014

Ferlisi S, Cascini L, Corominas J, Matano F (2012) Rockfall risk assessment to persons travelling in vehicles along a road: the case study of the Amalfi coastal road (southern Italy). Nat Hazards 62(2):691-721. https://doi.org/10.1007/s11069-012-0102-z

Ferlisi S, Peduto D, Gullà G, Nicodemo G, Borrelli L, Fornaro G (2015) The use of DInSAR data for the analysis of building damage induced by slow-moving landslides. In: Lollino G, Giordan D, Crosta GB, Corominas J, Azzam R, Wasowski J, Sciarra N (eds) Engineering geology for society and territory, Vol 2. Springer International Publishing, Cham, pp 1835-1839. https://doi.org/10.1007/978-3-319-09057-3_325

Ferlisi S, Gullà G, Nicodemo G, Peduto D (2019a) A multi-scale methodological approach for slow-moving landslide risk mitigation in urban areas, southern Italy. Euro-Mediterr J Environ Integr. https://doi.org/10.1007/s41207-019-0110-4

Ferlisi S, Nicodemo G, Peduto D, Negulescu C, Grandjean G (2019b) Deterministic and probabilistic analyses of the 3D response of masonry buildings to imposed settlement troughs. Georisk. https://doi.org/10.1080/17499518.2019.1658880

Ferretti A, Prati C, Rocca F (2001) Permanent scatterers in SAR interferometry. IEEE Trans Geosci Remote Sens 39(1):8-20. https://doi.org/10.1109/36.898661

Fotopoulou SD, Pitilakis KD (2013) Vulnerability assessment of reinforced concrete buildings subjected to seismically triggered slow-moving earth slides. Landslides 10(5):563-582. https://doi.org/10.1007/s10346-012-0345-5

Frattini P, Crosta GB, Rossini M, Allievi J (2018) Activity and kinematic behaviour of deepseated landslides from PS-InSAR displacement rate measurements. Landslides 15(6):1053-1070. https://doi.org/10.1007/s10346-017-0940-6

Galli A, di Prisco C (2013) Displacement-based design procedure for slope-stabilizing piles. Can Geotech J 50(1):41-53. https://doi.org/10.1139/cgj-2012-0104

Gullà G, Peduto D, Borrelli L, Antronico L, Fornaro G (2017) Geometric and kinematic characterization of landslides affecting urban areas: the Lungro case study (Calabria Southern Italy). Landslides 14(1):171-188. https://doi.org/10.1007/s10346-015-0676-0

Hackl J, Lam JC, Heitzler M, Adey BT, Hurni L (2018) Estimating network related risks: A methodology and an application in the transport sector. Nat Hazards Earth Syst Sci 18(8):2273-2293. https://doi.org/10.5194/nhess-18-2273-2018

Herrera G, Gutiérrez F, García-Davalillo JC, Guerrero J, Notti D, Galve JP, Cooksley G (2013) Multi-sensor advanced DInSAR monitoring of very slow landslides: the Tena Valley case study (Central Spanish Pyrenees). Remote Sens Environ 128:31-43. https://doi.org/10.1016/j.rse.2012.09.020

Ho KKS (2004) Recent advances in geotechnology for slope stabilization and landslide mitigation-perspective from Hong Kong. In: Lacerda W, Ehrlich M, Fontoura SAB, Sayão ASF (eds) Landslides: evaluation and stabilization. Proceedings of the ninth international symposium on landslides, Rio de Janeiro (Brazil), June 28-July 2, 2004, vol 2. (C) 2014 Taylor and Francis Group, London, pp 1507-1560

Ho KKS, Leroi E, Roberds B (2000) Quantitative risk assessment-application, myths and future direction. Proceeding of the International Conference on Geotechnical and Geological Engineering GeoEng2000, 19-24 November 2000, Lancaster: Technomic Publishing, Melbourne, Vol 1, pp 269-312

Hungr O, Evans SG, Hazzard J (1999) Magnitude and frequency of rock falls and rock slides along the main transportation corridors of southwestern British Columbia. Can Geotech J 36(2):224-238. https://doi.org/10.1139/t98-106

Hungr 0, Leroueil S, Picarelli L (2014) The Varnes classification of landslide types, an update. Landslides 11(2):167-194. https://doi.org/10.1007/s10346-013-0436-y

Infante D, Di Martire D, Confuorto P, Tessitore S, Ramondini M, Calcaterra D (2018) Differential SAR interferometry technique for control of linear infrastructures affected by ground instability phenomena. The International Archives of the Photogrammetry, Remote Sensing and Spatial Information Sciences, vol.XLII-3/W4, Geoinformation For Disaster Management (Gi4DM), 18-21 March 2018, Istanbul, Turkey. https://doi.org/ 10.5194/isprs-archives-XLII-3-W4-251-2018
Infante D, Di Martire D, Calcaterra D, Miele P, Scotto di Santolo A, Ramondini M (2019) Integrated procedure for monitoring and assessment of linear infrastructures safety (IPro MONALISA) affected by slope instability. Appl Sci 9(24):5535. https://doi.org/ 10.3390/app9245535

ISTAT (2019) http://dati.istat.it/index.aspx?queryid=34998\#. Accessed (last access: 30 December 2019)

Journault J, Macciotta R, Hendry MT, Charbonneau F, Huntley D, Bobrowsky PT (2018) Measuring displacements of the Thompson River valley landslides, south of Ashcroft, BC, Canada, using satellite InSAR. Landslides 15(4):621-636. https://doi.org/10.1007/ s10346-017-0900-1

Lagomarsino S, Giovinazzi S (2006) Macroseismic and mechanical models for the vulnerability and damage assessment of current buildings. Bull Earthq Eng 4(4):415-443. https://doi.org/10.1007/s10518-006-9024-z

Lentini V, Distefano G, Castelli F (2019) Consequence analyses induced by landslides along transport infrastructures in the Enna area (South Italy). Bull Eng Geol Environ 78(6):4123-4138. https://doi.org/10.1007/s10064-018-1390-7

Li ZH, Huang HW, Xue Y, Yin J (2009) Risk assessment of rockfall hazards on highways. Georisk 3(3):147-154. https://doi.org/10.1080/17499510902809763

Liang R, Geiger G, Beach K, Pensomboon G (2006) Landslide hazard rating system in Ohio DOT. In: Proceedings of ASCE GeoCongress 2006 on geotechnical engineering in the information technology age (CD-ROM)

Lowell S, Morin P (2000) Unstable slope management: Washington State. Transp Res News 207:11-15

Lu P, Catani F, Tofani V, Casagli N (2014) Quantitative hazard and risk assessment for slow-moving landslides from Persistent Scatterer Interferometry. Landslides 11(4):685-696. https://doi.org/10.1007/s10346-013-0432-2

Macciotta R, Derek Martin C, Morgenstern NR, Cruden DM (2016) Quantitative risk assessment of slope hazards along a section of railway in the Canadian Cordillera- a methodology considering the uncertainty in the results. Landslides 13(1):115-127. https://doi.org/10.1007/s10346-014-0551-4

Mansour MF, Morgenstern NR, Martin CD (2011) Expected damage from displacement of slow-moving slides. Landslides 8(1):117-131. https://doi.org/10.1007/s10346-0100227-7

Mavrouli 0, Fotopoulou S, Pitilakis K, Zuccaro G, Corominas J, Santo A, Cacace F, De Gregorio D, Di Crescenzo G, Foerster E, Ulrich T (2014) Vulnerability assessment for reinforced concrete buildings exposed to landslides. Bull Eng Geol Environ 73:265289. https://doi.org/10.1007/s10064-014-0573-0

Mavrouli 0, Corominas J, Ibarbia I, Nahikari Alonso N, loseba Jugo I, Ruiz J, Luzuriaga S, Navarro JA (2019) Integrated risk assessment due to slope instabilities in the roadway network of Gipuzkoa, Basque Country. Nat Hazards Earth Syst Sci 19(2):399-419. https://doi.org/10.5194/nhess-19-399-2019

Nappo N, Peduto D, Mavrouli 0, van Westen CJ, Gullà G (2019) Slow-moving landslides interacting with the road network: analysis of damage using ancillary data, in situ surveys and multi-source monitoring data. Eng Geol 260(2019). https://doi.org/ 10.1016/j.enggeo.2019.105244

Negulescu C, Foerster E (2010) Parametric studies and quantitative assessment of the vulnerability of a RC frame building exposed to differential settlements. Nat Hazards Earth Syst Sci 10(9):1781-1792. https://doi.org/10.5194/nhess-10-1781-2010

Negulescu C, Ulrich T, Baills A, Seyedi DM (2014) Fragility curves for masonry structures submitted to permanent ground displacements and earthquakes. Nat Hazards 74:1461-1474. https://doi.org/10.1007/s11069-014-1253-x

Nicodemo G, Peduto D, Ferlisi S, Gullà G, Borrelli L, Fornaro G, Reale D (2017) Analysis of building vulnerability to slow-moving landslides via A-DInSAR and damage survey data. In: Mikoš M, Tiwari B, Yin Y, Sassa K (Eds). Advancing culture of living with landslides - proc of the 4th world landslide forum, Ljubljana, Slovenia, May 29 June 02, 2017, ( 2017 Springer International Publishing Switzerland, Vol. 2, pp. 889907. https://doi.org/10.1007/978-3-319-53498-5 102

Nicodemo G, Ferlisi S, Peduto D, Aceto L, Gullà G (2020) Damage to masonry buildings interacting with slow-moving landslides: a numerical analysis. In: Calvetti $F$, Cotecchia F, Galli A, Jommi C (eds) Geotechnical research for land protection and development. CNRIG 2019. Lecture Notes in Civil Engineering, vol 40. Springer, Cham, pp 52-61. https://doi.org/10.1007/978-3-030-21359-6_6

North M, Farewell T, Hallet S, Bertelle A (2017) Monitoring the response of roads and railways to seasonal soil movement with persistent scatterers interferometry over six UK sites. Remote Sens 9:1-17. https://doi.org/10.3390/rs9090922

ODOT (2001) ODOT landslide and rockfall pilot study - final report. Geo-Hydro Section, HQ Geo-Hydro Unit, Salem

Pantelidis L (2011) A critical review of highway slope instability risk assessment systems. Bull Eng Geol Environ 70(3):395-400. https://doi.org/10.1007/s10064-010-0328-5 
Peduto D, Pisciotta G, Nicodemo G, Arena L, Ferlisi S, Gullà G, Borrelli L, Fornaro G, Reale D (2016) A procedure for the analysis of building vulnerability to slow-moving landslides. In: Daponte P, Simonelli AL (eds) Proc of the 1st IMEKO TC4 international workshop on metrology for geotechnics, Benevento, Italy, 17-18 March 2016, Curran Associates, Inc., Red Hook, NY 12571, USA @ 2016 International Measurement Confederation (IMEKO), Budapest, Hungary, pp 248-254

Peduto D, Ferlisi S, Nicodemo G, Reale D, Pisciotta G, Gullà G (2017) Empirical fragility and vulnerability curves for buildings exposed to slow-moving landslides at medium and large scales. Landslides 14(6):1993-2007. https://doi.org/10.1007/s10346-0170826-7

Peduto D, Nicodemo G, Caraffa M, Gullà G (2018) Quantitative analysis of consequences to masonry buildings interacting with slow-moving landslide mechanisms: a case study. Landslides 15(10):2017-2030. https://doi.org/10.1007/s10346-018-1014-0

Peduto D, Nicodemo G, Ferlisi S, Gullà G (2019) Probabilistic analysis of vulnerability of buildings to slow moving landslides: a study in two municipalities in southern Italy. In: Sigursteinsson H, Erlingsson S, Bessason B (eds) Proc. of the XVII European conference on soil mechanics and geotechnical engineering, ECSMGE-2019, Reykjavik Iceland, 1-6 September 2019, 8 pp. https://doi.org/10.32075/17ECSMGE-2019-0446

Pellicani R, Argentiero I, Spilotro G (2017) GIS-based predictive models for regional-scale landslide susceptibility assessment and risk mapping along road corridors. Geomat Nat Haz Risk 8(2):1012-1033. https://doi.org/10.1080/19475705.2017.1292411

Peng L, Xu S, Hou J, Peng J (2015) Quantitative risk analysis for landslides: the case of the Three Gorges area, China. Landslides 12:943-960. https://doi.org/10.1007/ s10346-014-0518-5

Picarelli L (2011) Discussion to the paper "Expected damage from displacement of slowmoving slides" by MF Mansour, NR Morgenstern and CD Martin. Landslides 8(4):553555. https://doi.org/10.1007/s10346-011-0292-6

Pitilakis KD, Fotopoulou SD (2015) Vulnerability assessment of buildings exposed to coseismic permanent slope displacements. In: Winter MG, Smith DM, Eldred PJL, Toll DG (eds) . ICE Publishing, Geotechnical engineering for infrastructure and development, pp 151-173. https://doi.org/10.1680/ecsmge.60678

Plank S, Singer J, Minet C, Thuro K (2012) Pre-survey suitability evaluation of the differential synthetic aperture radar interferometry method for landslide monitoring. Int J Remote Sens 33(20):6623-6637. https://doi.org/10.1080/01431161.2012.693646

Raspini F, Moretti S, Casagli N (2013) Landslide mapping using SqueeSAR data: Giampilieri (Italy) case study. In: Margottini C, Canuti P, Sassa K (eds) Landslide science and practice. Springer, Berlin, pp 147-154. https://doi.org/10.1007/978-3642-31325-7_19

Raspini F, Bardi F, Bianchini S, Ciampalini A, Del Ventisette C, Farina P, Casagli N (2017) The contribution of satellite SAR-derived displacement measurements in landslide risk management practices. Nat Hazards 86(1):327-351. https://doi.org/10.1007/s11069016-2691-4

Roberds W (2005) Estimating temporal and spatial variability and vulnerability. In: Hungr 0 , Fell $\mathrm{R}$, Couture $\mathrm{R}$, Eberhardt $\mathrm{E}$ (eds) Landslide risk management. Taylor and Francis, London, pp 129-157

Rosi A, Tofani V, Tanteri L, Stefanelli CT, Agostini A, Catani F, Casagli N (2018) The new landslide inventory of Tuscany (Italy) updated with PS-InSAR: geomorphological features and landslide distribution. Landslides 15(1):5-19. https://doi.org/10.1007/ s10346-017-0861-4

Saeidi A, Deck 0, Verdel T (2009) Development of building vulnerability functions in subsidence regions from empirical methods. Eng Struct 31(10):2275-2286. https:// doi.org/10.1016/j.engstruct.2009.04.010

Saeidi A, Deck 0, Verdel T (2012) Development of building vulnerability functions in subsidence regions from analytical methods. Géotechnique 62(2):107-120. https:// doi.org/10.1680/geot.9.P.028

Santangelo N, Santo A, Guida D, Lanzara R, Siervo V (2005) The geosites of the CilentoVallo di Diano National Park (Campania region, southern Italy). Ital J 0 Sci 18(1):103114

Shinozuka M, Feng MQ, Lee J, Naganuma T (2000) Statistical analysis of fragility curves. J Eng Mech 126(12):1224-1231

Shinozuka M, Feng Q, Kim HK, Uzawa T, Ueda T (2003) Statistical analysis of fragility curves. technical report MCEER-03-0002. State University of New York, Buffalo, pp 149

Tofani V, Raspini F, Catani F, Casagli N (2013) Persistent scatterer interferometry (PSI) technique for landslide characterization and monitoring. Remote Sens 5(3):10451065. https://doi.org/10.3390/rs5031045
Unterrader S, Almond P, Fuchs S (2018) Rockfall in the Port Hills of Christchurch: seismic and non-seismic fatality risk on roads. N Z Geogr 74(1):3-14. https://doi.org/10.1111/ nzg. 12170

van Westen CJ, Castellanos E, Kuriakose SL (2008) Spatial data for landslide susceptibility, hazard, and vulnerability assessment: an overview. Eng Geol 102(3-4):112-131. https://doi.org/10.1016/j.enggeo.2008.03.010

Vecchiotti F, Peduto D, Strozzi T (2017) Multi-sensor a priori PSI visibility map for nationwide landslide detection in Austria. In: Mikos M, Tiwari B, Yin Y, Sassa K (eds) Advancing culture of living with landslides, advances in landslide science Proc of the $4^{\text {th }}$ world landslide forum, 29 May - 2 June 2017, Ljubljana, Slovenia Springer, Cham, Vol 2, pp. 45-52. https://doi.org/10.1007/978-3-319-53498-5_6

Vishal V, Siddique T, Purohit R, Phophliya MK, Pradhan SP (2017) Hazard assessment in rockfall-prone Himalayan slopes along National Highway-58, India: rating and simulation. Nat Hazards 85(1):487-503. https://doi.org/10.1007/s11069-016-2563-y

Vranken L, Van Turnhout P, Van Den Eeckhaut M, Vandekerckhove L, Poesen J (2013) Economic valuation of landslide damage in hilly regions: a case study from Flanders, Belgium. Sci Total Environ 447:323-336. https://doi.org/10.1016/ j.scitotenv.2013.01.025

Wasowski J, Bovenga F (2014) Investigating landslides and unstable slopes with satellite multi temporal interferometry: current issues and future perspectives. Eng Geol 174:103-138. https://doi.org/10.1016/j.enggeo.2014.03.003

Wasowski J, Bovenga F (2015) Remote Sensing of landslide motion with emphasis on satellite multitemporal interferometry applications: An overview. In: Davies T (ed) Landslide hazards, risks and disasters. Elsevier Inc., Amsterdam, pp 345-403. https:// doi.org/10.1016/B978-0-12-396452-6.00011-2

Winter MG (2018) The quantitative assessment of debris flow risk to road users on the Scottish trunk road network: A85 Glen Ogle Wokingham: Transport Research Laboratory Published Project Report PPR 799

Winter MG (2019) Landslide hazards and risks to road users, road infrastructure and socio-economic activity. Invited lecture. In: Sigursteinsson H, Erlingsson S, Bessason B (eds) Proc. of the XVII European conference on soil mechanics and geotechnical engineering, ECSMGE-2019, Reykjavik Iceland, 1-6 September 2019, 33 pp. https:// doi.org/10.32075/17ECSMGE-2019-1118

Winter MG, Wong JCF (2020) The assessment of quantitative risk to road users from debris flow. Geoenviron Disast 7, Article number: 4. https://doi.org/10.1186/s40677019-0140-x

Wong CKL (1998) The new priority classification systems for slopes and retaining walls. GEO Report No. 68. Geotechnical Engineering Office, Civil Engineering Department, The Government of the Hong Kong Special Administrative Region, Hong Kong Government Press, Hong Kong, $117 \mathrm{pp}$

Wong HN (2005) Landslide risk assessment for individual facilities. In: Hungr 0, Fell R, Couture R, Eberhardt $\mathrm{E}$ (eds) Landslide risk management. Taylor and Francis, London, pp 237-296

Wong JFC, Winter MG (2018) The quantitative assessment of debris flow risk to road users on the Scottish trunk road network: A83 rest and be thankful. Wokingham: Transport Research Laboratory. Published Project Report PPR 798

Wong HN, Ho KKS, Chan YC (1997) Assessment of consequence of landslides. In: Cruden $\mathrm{R}$, Fell R (eds) Landslide risk assessment. Balkema, Rotterdam, pp 111-149

Zhang LM, Ng AMY (2005) Probabilistic limiting tolerable displacements for serviceability limit state design of foundations. Géotechnique 55(2):151-161. https://doi.org/ 10.1680/geot.2005.55.2.151

S. Ferlisi - A. Marchese - D. Peduto $(\bullet)$

Department of Civil Engineering,

University of Salerno,

via Giovanni Paolo II, 132, 84084, Fisciano, Salerno, Italy

Email: dpeduto@unisa.it

S. Ferlisi

e-mail: sferlisi@unisa.it

A. Marchese

e-mail: amarchese@unisa.it 